IFN Working Paper No. 954, 2013

\title{
Hierarchies and Entrepreneurship
}

Joacim Tåg, Thomas Åstebro and Peter Thompson 


\title{
Hierarchies and Entrepreneurship
}

\author{
Joacim Tåg* \\ Research Institute of Industrial Economics (IFN) \\ Thomas Åstebro** \\ HEC Paris \\ Peter Thompson*** \\ Georgia Institute of Technology
}

May 2016

\begin{abstract}
We establish a correlation between the hierarchical structure of a firm and the likelihood of business creation among its former employees, using a sample of 16 million observations of Swedish workers and a novel proxy for hierarchies based on occupation data. Conditional on firm size and many other variables, employees in firms with more layers are less likely to enter entrepreneurship, to become self-employed, and to switch to another employer. The effects of layers are much stronger for business creation than for job-switching and they are stronger for entrepreneurship than for self-employment. We discuss two potential explanations for the distinctive hierarchy effect we find. Part of the effect could be to be due to preference sorting by employees, and part due to employees in firms with fewer layers having a broader range of skills. One test showing that the probability of entrepreneurship increases with their prior rank in an organization is consistent with ability sorting and inconsistent with preference sorting.
\end{abstract}

Key words: entrepreneurship; employee mobility; hierarchy, rank, small firm effect. JEL codes: L26, D20, J20, M50.

\footnotetext{
*Research Institute of Industrial Economics (IFN), Box 55665, SE-102 15 Stockholm, Sweden. Email: joacim.tag@ifn.se. Joacim gratefully acknowledges financial support from Vinnova, the Jan Wallander and Tom Hedelius Foundation, and the Marianne and Marcus Wallenberg Foundation. **HEC Paris, 1 rue de la Liberation, 78351 Jouy-en-Josas Cedex, France. Email: astebro@hec.fr. Thomas gratefully acknowledges financial support from HEC Foundation and the HEC Leadership Center. ${ }^{* * *}$ Scheller College of Business, Georgia Institute of Technology, $800 \mathrm{~W}$. Peachtree Street NW, Atlanta, GA 30308, USA. Email: peter.thompson@scheller.gatech.edu. We thank Tino Sanandaji and participants in seminars in Amsterdam, Bergen, Cambridge, Copenhagen, Leuven, Lund, Madrid, Milano, and Uppsala for excellent comments and suggestions. We also thank Sebastian Jävervall for outstanding research assistance.
} 


\section{Introduction}

Compared with their counterparts in large firms, workers in small firms are more likely to separate from their employers (Anderson and Meyer, 1994; Lazear and Shaw, 2008) and those that leave small firms are more likely to become entrepreneurs or self-employed than those leaving large firms (Wagner, 2004; Dobrev and Barnett, 2005; Gompers, Lerner and Scharfstein, 2005; Elfenbein, Hamilton and Zenger, 2010; Chen, 2012). One candidate explanation for this "small firm effect" is the segregation of worker types into large and small firms. Indeed, Elfenbein et al. (2010) use self-reported data on whether individuals have a desire to become entrepreneurs to show that individuals with this desire are overrepresented in small firms, and are more likely to subsequently establish a business.

Small firms attract individuals with preferences and abilities for entrepreneurship not just because they are smaller, but because they are different. In particular, large firms are generally more hierarchical and bureaucratic, characteristics that may induce them to assign less value to skills appropriate for entrepreneurship and that repel workers with a preference for autonomy and work variety. Unfortunately, research on the effect of organizational bureaucracy on transitions to entrepreneurship has been limited to date by its reliance on potentially crude proxies, notably firm size and age (e.g., Dobrev and Barnett, 2005; Sørensen , 2007; Kacperczyk, 2012). ${ }^{1}$ But the fact that firm size is inversely related to entrepreneurship might be due to a host of reasons. For example, small and young firms are much more likely to go out of business than their counterparts (Haltiwanger, Jarmin and Miranda, 2013), thus mechanically creating a negative correlation between both firm size and firm age with entrepreneurship.

In this paper, while controlling for firm size and age effects, our objective is to use two well-established measures of the hierarchical structure of the firm in order to examine their correlation with entrepreneurship. First, we use the number of levels of decisionmaking in the hierarchy. Second, we measure the span of control. These two measures represent two out of three basic structural mechanisms used to help coordinate divided tasks (Griffin and Moorehead, 2014, p. 438) and which appear with greater size and age of firms. ${ }^{2}$ Entrepreneurship is a rare event, and analysing its correlation with the hierarchical structure of the firm requires an extensive dataset on the hierarchical structure of firms. Typically, such datasets have not been available which has restricted analysis

\footnotetext{
${ }^{1}$ Defending the choice of using firm size and age as representative measure of bureaucracy, Sørensen (2007) writes: “An organization's degree of bureaucratization is not directly observable. Moreover, constructing and collecting specialized measures of hierarchy, role specialization, and routinization in the large samples needed to capture transitions to entrepreneurship is prohibitively difficult." (p. 395)

${ }^{2}$ The third mechanism is departmentalization - the manner in which divided tasks are combined and allocated to work groups (Griffin and Moorehead, 2014, p. 438). Our data do not allow us to capture this mechanism with any precision.
} 
of the hierarchical structure of firms to small sample sizes. In contrast, our sample is drawn from the Swedish matched employer-employee dataset, and consists of over 240,000 firm-level observations and 16 million individual-level observations over the period 2001-2008. Following the pioneering work of Caliendo and Rossi-Hansberg (2012) and Caliendo, Monte and Rossi-Hansberg (2015), we use employees' job titles to classify them into one of up to four ranks in their organization (CEOs, senior staff, supervisors, and production workers). We then measure the hierarchal structure of the firm by counting the number of distinct ranks that are represented in the firm, which we refer to as the number of layers. We also count the number of employees at each rank and compute the span of control as the ratio of the number of employees at a lower rank to the number at the next higher rank, and average this measure across all adjacent ranks in the organization. Our data allow us to create these two measures for all firms with at least two employees in an economy. ${ }^{3}$ Our sample behaves as one would expect from a meaningful measure of a pyramidal hierarchy: higher ranks contain fewer employees and pay higher wages than lower ranks, and employee transitions are most likely to be to an adjacent rank.

Section 2 describes our data. In Section 3, we demonstrate that the number of layers in the firm has a large effect on the likelihood of entrepreneurship. Conditional on firm size and age, employees in firms with more layers are less mobile. This is true regardless of the mover's destination, but the effect of layers on business creation is greater than its effect on relocation to other incumbent firms. We decompose business creation into selfemployment and entrepreneurship, defined by the legal form of business that is created. More layers in a firm suppress both types of business creation, but the effect is especially pronounced for entrepreneurship.

In Section 4, we discuss two prominent arguments -- sorting by preference and sorting by ability -- for why bureaucracy should be correlated with entrepreneurship. We first look at evidence for the preference sorting hypothesis. Individuals with a strong preference for entrepreneurship should be more willing to establish businesses that yield low financial returns, and they should also persist in business for longer. We test these implications, and conclude that employees of less hierarchical firms do behave in ways consistent with preference sorting. We then assess whether there are differences in entrepreneurial ability among employees of firms with different numbers of layers. We frame this analysis around Garicano (2000) and Caliendo and Rossi-Hansberg's (2012) information-processing model, which relates the number of layers in a firm to the breadth of problems that employees at different ranks are expected to be able to solve.

\footnotetext{
${ }^{3}$ It should be noted that with a given number of employees, a relatively tall structure (many hierarchical levels) must necessarily have a narrower average span of control, and so we will examine whether there is any added value of including both measures compared with using just one.
} 
Although they do not study their model's implications for employee separations, we derive and test two implications. First, employees in firms of a given size but with fewer layers should have a higher propensity to enter entrepreneurship and self-employment and to be more successful when they do. Our evidence on business creation rates is consistent with the information-processing model (but also with preference sorting); our evidence on earnings do not support the model. Second, the propensity for business creation is greater when employees of a given rank have more layers beneath them. We find strong support for this prediction.

\section{The Data}

The data are drawn from the Statistics Sweden's LISA database drawing on several official registry databases of every person living in Sweden. We obtain information for employed workers on occupation codes, firm-worker links, worker's labor income, worker's capital income, and numerous other worker characteristics. We also obtain information on firm age for limited liability firms from the Swedish Companies Registrations Office. We make use of data for the period 2001-2008 for entry data and 20042011 for start-up performance data. ${ }^{4}$ We then restrict our attention to individuals between the ages of 20 and 60 employed in firms with more than one employee (this is our initial dataset).

Because we will construct indicators of employee rank and organizational structure from information on occupational codes assigned by Statistics Sweden, we further restrict our sample to include only firms with sufficient occupation data for its employees. In LISA, 70 percent of all potential individual-level observations contain occupation data for the relevant year and firm-worker link as the occupation data is based on surveys that do not have complete coverage. Because occupation data is not complete for every year, we drop firm-year observations with fewer than 75 percent of all employees in a firm having accurate occupation data. This affects observations mainly from smaller firms that are less likely to be sampled by Statistics Sweden. ${ }^{5}$ In our final sample, 90 percent of all individual-level observations contain occupation data, which covers 62 percent of all individual-year observations in the initial dataset.

In each year, we track whether employees remained with their current firm, switched

\footnotetext{
${ }^{4}$ Accurate occupation data is only available from 2001 and onwards. Worker level information is, however, available from 1990 and onwards. We use information from prior to 2001 to construct measures of worker tenure, worker wage growth, and firm age for unlimited liability firms. For worker tenure and firm age, we include truncation dummies in the regressions to account for the fact that we only observe firms and worker employment histories back to 1990 .

${ }^{5}$ In robustness analysis (in an appendix available from the authors) we test whether dropping firm-year observations with fewer than 90, 95 and 99 percent of all employees in a firm having accurate occupation data change our results. The key results we report in Section 3 are unchanged.
} 
to another incumbent firm, or created and became primarily occupied in running their own business. ${ }^{6}$ We follow the practice used by Statistics Sweden to define entrepreneurs and the self-employed. Statistics Sweden defines an individual as being employed in her own firm in a given year if her total income from her own company (labor and capital income) is greater than 62.5 percent of all other labor income. ${ }^{7}$ This is a stricter criterion than just reporting to be an owner of a business or reporting some earnings from a business. We define an individual as entering entrepreneurship in any given year if the following criteria are simultaneously fulfilled:

1. Newly occupied in own business. An individual is classified by Statistics Sweden as working in her own company in the current year, but had not been in the previous year.

2. New place of work. The individual's current firm and establishment identifiers are different from the previous year, and

3. New firm. No individual in our sample had worked for the current firm in the previous year.

Statistics Sweden also separates sole proprietorships from limited liability companies. Because an individual who intends to create a growing company likely will establish a limited liability company, we characterize agents starting limited liability companies as "entrepreneurs", and agents starting sole proprietorships "self-employed".8

Table 1 displays numbers on the sample size of the final dataset. It contains 243,689 firm-year observations covering 61 percent of value added and 53 percent of employment in the Swedish private sector. Of around 16.5 million employee-level observations, about 9.5 percent transition to a new incumbent employer in each year, about 0.28 percent enter self-employment, while just 0.06 percent enter entrepreneurship. The number of firms in the sample varies considerably across years, a result of different sampling of occupation codes and industry sectors over time. Differences in sampling frames across years will be dealt with by industry and year dummies in regressions.

\footnotetext{
${ }^{6}$ All other employee exits (such as moves to unemployment or moves abroad) are ignored: we drop these observations at the time of exit. The appendix provides robustness analysis where we include moves to unemployment in the analysis.

${ }^{7}$ Statistics Sweden treats self-employment as the primary occupation even though it may generate less income than other activities, because self-employment typically generates lower hourly wages.

8 These labels are arbitrary. We could instead have used the terms "growth" and "life-style" entrepreneurs. The mean size of a limited liability company two years after creation is 5.3 employees with a standard deviation of 10.5, while the mean size of a sole proprietorship is 1.2 employees with a standard deviation of 0.75. Henrekson and Sanandaji (2013) survey the literature on entrepreneurship and self-employment and demonstrate the importance of separating between entrepreneurs and the self-employed using data on billionaire entrepreneurs.
} 
Table 1

Sample size

\begin{tabular}{cccccc}
\hline \hline Year & Firms & Workers & To other firm & $\begin{array}{c}\text { To self } \\
\text { employment }\end{array}$ & $\begin{array}{c}\text { To } \\
\text { entrepreneurship }\end{array}$ \\
\hline 2001 & 44,959 & $2,011,755$ & 206,443 & 5,167 & 673 \\
2002 & 36,289 & $2,112,875$ & 191,439 & 5,084 & 542 \\
2003 & 28,574 & $2,039,069$ & 186,524 & 6,149 & 1,304 \\
2004 & 23,637 & $2,003,621$ & 176,524 & 6,151 & 1,248 \\
2005 & 22,481 & $2,033,432$ & 189,111 & 6,305 & 1,263 \\
2006 & 27,822 & $2,071,002$ & 221,266 & 5,609 & 1,516 \\
2007 & 32,211 & $2,138,253$ & 200,666 & 5,896 & 1,927 \\
2008 & 27,716 & $2,075,520$ & 179,036 & 5,463 & 1,154 \\
\hline Total & 243,689 & $16,485,527$ & $1,551,009$ & 45,824 & 9,627 \\
\hline \hline
\end{tabular}

\subsection{Occupation classifications, rank and layers}

Our data on the hierarchical structure of firms are developed from occupational classifications obtained from Statistics Sweden's LISA database. The Swedish Standard Classification of Occupations 1996 (SSYK) is a Swedish version of the International Standard Classification of Occupations (ISCO-88). At the level of aggregation we are interested in, the two classification schemes are close to identical. The SSYK data available from the LISA database come mainly from the official wage statistics survey (Lönestrukturstatistiken) and from a supplementary survey of firms not included in the official wage survey. The SSYK assigns workers to one of ten main occupational categories, and one of a large number of subcategories. This assignment is a precise definition of an individual's job duties. Statistics Sweden also assigns each of these occupational categories to one of four skill levels. ${ }^{9}$

Between the two surveys, at least 40,000 firms are sampled every year. The sampling design is a rolling panel, and all eligible firms are surveyed at least once every five years. Firms with at least 500 employees, however, are always included. Not all firms are included in these surveys. The largest excluded category is of self-employed workers who do not obtain any wage from a limited liability company, but the surveys also exclude owners who receive payment from their companies only in the form of dividends. ${ }^{10}$

\footnotetext{
${ }^{9}$ Statistics Sweden notes that, although these skill levels have been made operational in terms of the educational categories of the International Standard Classification of Education, they do not imply that the skills necessary to perform the tasks and duties of a given job can be acquired only through formal education. Except for displaying these skill levels in Table 2, we make no use of them.

10 There have been some attempts since 2004 to survey partnerships and sole proprietorships
} 
Firms in our sample are therefore not representative of the entire population of firms. ${ }^{11}$ However, despite these exclusions, there are good reasons to expect our findings to be representative of the population of larger firms. For larger firms, the occupation data is either collected for all firms above a size cutoff or collected through random sampling of firms conditional on firm size and industry affiliation. The sampling variations will be controlled for with dummy variables in our analysis. However, to confirm our intuition that the final sample we use is representative, we also report in the appendix available from the authors output from a regression using sample weights. Our results remain virtually unchanged when accounting for the sample selection in this manner. A drawback of the final sample is, however, that due to the use of rolling panels we do not typically observe the hierarchical structure of a given firm for many years making it difficult to use firm fixed effects in our analysis.

Following the empirical method developed by Caliendo et al. (2015) for French occupational data and re-examined by Tåg (2013) on Swedish occupational data for manufacturing industries, we use the SSYK codes to assign a rank to each employee in firms with more than one employee (see Table 2). The idea behind the classification is to group a set of workers with similar levels of knowledge to the same rank, representing a particular layer in the hierarchy. We chose to classify individuals into four ranks on the basis that this classification has been shown by Caliendo et al. (2015) and Tåg (2013) to yield logically consistent hierarchical structures. Caliendo et al. (2015) use the PCS-ESE classification for their analysis, which differs somewhat from the classification we use here. However, as shown in Tåg (2013), both the classification we use here and a classification based on mapping the PCS-ESE codes to the Swedish SSYK codes yield similar results in terms of generating hierarchical structures that correspond to theoretical predictions.

We will also show in the next few tables that we obtain similarly consistent hierarchies. Workers in different occupations are classified into ranks on the basis of their wages, which should proxy for the knowledge of workers. The highest rank, which we label CEOs, consists of directors, chief executives, managers of small enterprises, and certain other senior officials. The next two ranks comprise two levels of management. The more senior, which we label as "Senior staff", contains production and operations managers and certain other specialist managers. The less senior, "Supervisors", consists of workers with occupations classified in the SSYK as professionals, technicians and associate professionals. The fourth category, "Production workers", comprises clerks, service workers, plant and machine operators, and other non-supervisory positions. For firms with only one reported rank of workers, we designate the highest paid individual to be

but the coverage is extremely limited.

11 The appendix details the differences between the base sample and the final sample we use for the analysis. Sample selection is apparent since all variables listed in the appendix are statistically different in means at the $1 \%$ level. 
a rank above all other workers. ${ }^{12}$ As Table 2 shows, our rank classifications broadly coincide with the skill levels attributed to these positions by Statistics Sweden, which at first blush makes the classification method seem reasonable in grouping a set of workers with similar levels of knowledge to the same rank.13

Table 2

Occupational classifications, skill levels, and rank

\begin{tabular}{ccl}
\hline \hline SYYK Occupational Classification & Skill Level & \multicolumn{1}{c}{ Rank } \\
\hline \hline 1. Legislators, senior officials \& managers & NA & $\begin{array}{l}\text { 4. CEOs: SSYK 121 (Directors and chief ex- } \\
\text { ecutives), 131 (Managers of small enter- } \\
\text { prises), 111 (legislators and senior govern- }\end{array}$ \\
& & $\begin{array}{l}\text { ment officials), 112 (senior officials of spe- } \\
\text { cial-interest organizations) }\end{array}$
\end{tabular}

3. Senior staff: SSYK 122 (Production and operations managers), 123 (Other specialist managers)

2. Professionals 4 2. Supervisors: SSYK 200-399 (Profes-

3. Technicians \& associate professionals $\quad 3$ sionals, technicians and associate professionals)

\begin{tabular}{lcl}
\hline 4. Clerks & 2 & 1. Production workers: SSYK 400-999 \\
5. Service workers \& shop sales workers & 2 & (Clerks, service workers and shop sales \\
6. Skilled agricultural \& fishery workers & 2 & workers, skilled agricultural and fishery \\
7. Craft \& related trades workers & 2 & workers, craft and related trades workers, \\
$\begin{array}{l}\text { 8. Plant \& machine operators \& assemblers } \\
\text { 9. Elementary occupations }\end{array}$ & 2 & plant and machine operators and assem- \\
\hline 0. Armed forces & 1 & blers, and elementary occupations). \\
\hline
\end{tabular}

\footnotetext{
${ }^{12}$ A handful of small firms contain employees all having the rank "CEO". We drop these aberrant firms from the sample.

${ }^{13}$ Using fewer ranks would not be reasonable, in light of the distribution of wages across ranks displayed in Table 3. If a rank is supposed to consist of workers of similar levels of knowledge, and wages proxy for knowledge, we would be grouping workers of different knowledge levels together. It would perhaps be possible to consider using more than four ranks. Such a classification would need to be based on a wider distribution of occupation categories than those displayed in Table 3. One possibility we considered was to use the nine SSYK codes displayed in the left hand column of Table 2 as nine ranks. However, while there are some differences in average wages across the nine categories, the hierarchical structures that result frequently fail to induce structures that resemble those we would be expecting, with fewer and higher paid workers in higher ranks.
} 
Do our classifications induce patterns consistent with our notions of rank and hierarchies? We look first at earnings by rank. The earnings data we use throughout the paper measure each individual's annual labor income. However, for compactness, we will generally refer to our earnings measure as the "wage". Table 3 displays the wage distribution by rank, which are overwhelmingly consistent with our goal of grouping a set of workers with similar levels of knowledge to the same rank. Workers in higher ranks tend to earn more on average than workers in lower ranks, with the notable exception that Senior staff on average earn more than the CEO rank at all but the highest percentiles. However, this exception does not imply that Senior staff earn more than their immediate managers. Instead individuals with the occupation code 131 "Managers of small enterprises", who belong to the CEO rank, typically earn less than Senior staff in large enterprises, therefore creating the illusion that Senior staff earn more than their immediate managers. Further analysis in the appendix details these pooling effects, ${ }^{14}$ which we control for by including firm size in all regressions. The table also shows that the within-rank wage distribution is lowest at the bottom rank and increases monotonically with rank, as would be expected from the theory of firms as knowledge hierarchies, due to the greater ability of more knowledgeable workers to leverage minor skill differences for greater pay (Garicano and Rossi-Hansberg, 2004).

Table 3

Wage distribution across broad occupation classes based on SSYK

\begin{tabular}{lccccccc}
\hline \hline \multirow{2}{*}{ Rank } & Mean & \multicolumn{5}{c}{ Percentiles } & Wage \\
\cline { 3 - 7 } & & $10^{\text {th }}$ & $25^{\text {th }}$ & $50^{\text {th }}$ & $75^{\text {th }}$ & $90^{\text {th }}$ & Dispersion \\
\hline 4. CEOs and directors & 523 & 217 & 285 & 368 & 565 & 940 & 1,114 \\
3. Senior staff & 505 & 293 & 359 & 444 & 575 & 761 & 678 \\
2. Supervisors & 308 & 159 & 228 & 285 & 359 & 469 & 453 \\
1. Production workers & 219 & 112 & 172 & 222 & 266 & 313 & 264 \\
\hline Mean & 272 & 131 & 195 & 251 & 317 & 415 & 373 \\
\hline \hline
\end{tabular}

Data are in units of 1,000 SEK in 2005 prices. Sample sizes are as follows. Rank 4: 109,194. Rank 3: 366,927. Rank 2: 5,628,096. Rank 1: 5,665,137.

Table 4 plots rank transitions among workers remaining with the same firm. Transition rates decline with distance between rank pairs, and most employees do not change rank. For example, 94.3 percent of production workers are at the same rank three years later, while 5.1 percent are at the rank of supervisor and less than one percent have attained either of the two highest ranks. Among those that do switch rank, moving one rank is

\footnotetext{
14 In addition, if we add capital income to wages, Rank 3 employees earn on average much more than Rank 2 employees, See appendix for details.
} 
much more likely than moving two for all ranks except CEOs, who exhibit the greatest mobility. ${ }^{15}$ Tables 3 and 4 together suggest that our occupational classifications succeed in capturing a form of distance consistent with our notion of ranks and hierarchies. ${ }^{16}$

Our remaining descriptive analysis focuses on two measures of the structure of organizations: the number of layers in the firm and the span of control. The number of layers is simply the number of distinct ranks occupied in a given firm. As we assign the highestpaid employee to be CEO when the data indicate only a single layer, firms may have two, three or four layers. We count the number of employees at each rank and compute the span of control as the ratio of the number of employees at a lower rank to the number at the next higher rank, and average this measure across all adjacent ranks for a firmyear observation.

Table 4

Rates of within-company rank transitions

\begin{tabular}{lcccc}
\hline \hline & $\begin{array}{c}\text { To production } \\
\text { worker }\end{array}$ & $\begin{array}{c}\text { To } \\
\text { supervisor }\end{array}$ & $\begin{array}{c}\text { To } \\
\text { senior staff }\end{array}$ & To CEO \\
\hline Production worker & $\mathbf{9 4 . 3}$ & 5.12 & 0.40 & 0.19 \\
Supervisors & 3.96 & $\mathbf{9 3 . 3}$ & 2.24 & 0.47 \\
Senior Staff & 3.25 & 19.3 & $\mathbf{7 2 . 1}$ & 5.39 \\
CEO or director & 5.44 & 13.0 & 16.0 & $\mathbf{6 5 . 6}$ \\
\hline \hline
\end{tabular}

Transition rates over a three-year period if available; otherwise two years, otherwise one year.

Table 5 provides information about within-firm differences in layer populations and in earnings across layers as a function of the number of layers in the firm. Panel $A$ of the table documents the mean number of employees in each layer, while Panel B provides the probabilities that a lower layer contains more employees than the layer immediately

15 Table 4 indicates a somewhat perplexing 5.4 percentage chance that a person at the highest
rank moves down to the lowest rank in a firm within three years. However, reporting of occupa-
tion is not without measurement error. In particular, we have analyzed all transitions in the bot-
tom left hand corner of Table 4 and found that many of these appear to be misclassifications of
temporary workers such as consultants or trade workers that report through their temporary
employer to be a CEO (as they are in their own consulting/trades firm), and that this later gets
corrected to their true occupation at their temporary employer. Further, this row percentage is
a small fraction of all moves. When we compute the global percentages of Table $4:$ a) on the
diagonal; b) above the diagonal (=promotions); and c) below the diagonal (=demotions), $92.8 \%$
remain in their rank, $4.3 \%$ are promoted, and $2.9 \%$ are demoted. In a paper using related data
from Sweden, Lazear and Oyer (2004) find that the incidence of demotions is $2.1 \%$. Demotions
are thus quite infrequent overall even when including apparent measurement error.
16 Transition rates between ranks are very similar if we include employees that switched firms. 
above it in the firm as a function of the number of layers. In the large majority of cases, the firm's structure corresponds to our notion of hierarchies as triangular structures, where higher layers consist of small numbers of people supervising larger groups of workers in lower layers. For example, in firms with only two layers, the lower of the two has more workers in 92 percent of the firm-year observations, and the lower layer contains on average more than three times as many employees. Note also that firms with more layers tend to be much larger: firms with just two layers have on average ten employees, compared with 55 and 427 among firms with three and four. Panels C and D compare earnings across layers. They show that in the majority of firms members of a given layer earn more on average than workers in the layer immediately below them in the firm.

Table 5

Size and wage by layers

\begin{tabular}{|c|c|c|c|c|c|c|c|c|c|}
\hline \multirow[b]{2}{*}{ No. of Layers } & \multicolumn{5}{|c|}{$\begin{array}{c}\text { A } \\
\text { Mean Size of Layer }\end{array}$} & \multicolumn{4}{|c|}{$\begin{array}{c}\text { C } \\
\text { In Wage in Layer }\end{array}$} \\
\hline & $\begin{array}{c}\text { Layer } \\
1\end{array}$ & $\begin{array}{c}\text { Layer } \\
2\end{array}$ & $\begin{array}{c}\text { Layer } \\
3\end{array}$ & $\begin{array}{c}\text { Layer } \\
\quad 4\end{array}$ & Total & $\begin{array}{c}\text { Layer } \\
1 \\
\end{array}$ & $\begin{array}{c}\text { Layer } \\
2\end{array}$ & $\begin{array}{c}\text { Layer } \\
3\end{array}$ & $\begin{array}{c}\text { Layer } \\
4\end{array}$ \\
\hline 2 & 7.6 & 2.2 & & & 9.8 & 210.9 & 307.3 & & \\
\hline 3 & 30.2 & 22.2 & 3.0 & & 55.4 & 229.1 & 312.1 & 470.8 & \\
\hline 4 & 244.7 & 206.2 & 16.5 & 5.3 & 427.2 & 235.1 & 327.3 & 497.9 & 887.3 \\
\hline \multirow[t]{2}{*}{ Total } & 44.0 & 33.7 & 8.3 & 5.3 & 91.3 & 217.8 & 311.0 & 481.6 & 887.3 \\
\hline & \multicolumn{5}{|c|}{$\begin{array}{l}\text { B } \\
\text { Fraction of firms with more employees in lower } \\
\text { layer than in next higher layer. }\end{array}$} & $\begin{array}{l}\text { Fraction } \\
\text { in lowe } \\
\end{array}$ & $\begin{array}{l}\text { firms } \mathrm{n} \\
\text { layer th }\end{array}$ & $\begin{array}{l}\text { lower } \\
\text { in next }\end{array}$ & $\begin{array}{l}\text { ean wage } \\
\text { yer up. }\end{array}$ \\
\hline No. of Layers & \multicolumn{2}{|c|}{$1>2$} & $2>3$ & \multicolumn{2}{|c|}{$3>4$} & $1<2$ & \multicolumn{2}{|c|}{$2<3$} & $3<4$ \\
\hline 2 & \multicolumn{2}{|c|}{0.92} & & & & 0.88 & & \\
\hline 3 & \multicolumn{2}{|c|}{0.69} & 0.91 & & & 0.86 & \multicolumn{2}{|c|}{0.86} & \\
\hline 4 & \multicolumn{2}{|c|}{0.60} & 0.92 & \multicolumn{2}{|c|}{0.92} & 0.95 & \multicolumn{2}{|c|}{0.93} & 0.82 \\
\hline
\end{tabular}

The layer numbers do not necessarily correspond to the rank numbers used in Table 2 . For example, a firm with one CEO and several blue-collar workers will have two layers and consist of workers in ranks 3 and 0. Such firms will appear in the same cells as firms consisting only of, for example, ranks 3 and 2. Sample sizes: 2-layer firms: $N=161,861$; 3-layer firms: $N=49,043$; 4-layer firms: $N=32,785$.

Table 6 provides summary statistics on our second measure of bureaucracy, the span of control. The mean firm span of control is 6.17 with a standard deviation of 17.4. Span of control is greater in larger firms and in firms with more layers. These summary statistics indicate that firm span of control is positively correlated with both the number of layers and firm size. 
Table 6

Span of control by firm size and number of layers

\begin{tabular}{ccccc}
\hline $\begin{array}{c}\text { Number of } \\
\text { Layers }\end{array}$ & $\begin{array}{c}\text { No. of employees per } \\
\text { immediate supervisor }\end{array}$ & & $\begin{array}{c}\text { Firm size } \\
\text { (employees) }\end{array}$ & $\begin{array}{c}\text { No. of employees per } \\
\text { immediate supervisor }\end{array}$ \\
\cline { 1 - 2 } \cline { 5 - 5 } 2 & 5.73 & & $50-100$ & 13.54 \\
3 & 6.70 & & $100-500$ & 15.31 \\
4 & 7.62 & & $500-1,500$ & 18.42 \\
& & & $>1,500$ & 31.80 \\
\hline \hline
\end{tabular}

The results reported in Tables 3 through 6 are consistent with Tåg (2013) and confirm the findings in Caliendo et al. (2015) for the case of Sweden. The remainder of the paper focuses on new findings about the association between the hierarchical structure of the firm and new firm formation.

\section{Hierarchies and Mobility}

In this section we explore the relationship between worker mobility, especially into entrepreneurship and self-employment, and the hierarchical structure of the firm. Table 7 reports the main results of this section. We estimate multinomial logit regressions with four possible outcomes in each year: remain with the current employer, enter entrepreneurship, enter self-employment, and switch to another employer. ${ }^{17}$ In all regressions, we cluster the standard errors at the firm level. The key result here is that an increase in the number of layers is negatively associated with mobility of all types, although the effect is much stronger for entry into entrepreneurship and self-employment than it is for moving to another employer. Subsequently, Table 8 reveals that an increase in the span of control is associated with an increase in movement to other employers but a decline in the likelihood of business creation; the magnitude of the effects of changes in the span of control is, however, very small.

${ }^{17}$ In the appendix we also take into account transitions to unemployment. 


\subsection{Control variables}

Before looking at the key results in more detail, we review the results concerning the controls in the regressions. Firm age and firm size have the customary effects on entrepreneurship. Although the quadratic terms suggest non-monotonic effects, the magnitudes of the coefficients indicate negative relationships between size and age, and the likelihood of entrepreneurship. As is the case in most samples, employee tenure is negatively associated with mobility of all kinds, ${ }^{18}$ while the more educated ${ }^{19}$ and males are more mobile regardless of destination. Interestingly, individual wages have impacts that differ by destination. Individuals with higher wages are less likely to switch to another incumbent employer and less likely to enter self-employment. However, a higher wage is associated with an increase in the propensity to become an entrepreneur. The contrasts between these effects of individual wages are not only statistically significant, they are economically meaningful. For example, a one standard deviation increase in log income is associated with a decline in the odds of switching employers (relative to staying with the current employer) of 15 percent, with a decline in the odds of entering selfemployment of 38 percent, but with an increase in the odds of entering entrepreneurship of 4.4 percent. Employee age similarly has disparate effects on mobility by destination. Increasing age raises the probability of entering entrepreneurship and self-employment until a peak hazard is attained at 38 years of age for entrepreneurship and 49 years for self-employment, after which the hazard declines. In contrast, increasing age reduces the probability of switching incumbent employers throughout the entire age range covered in our sample.

These results for the control variables suggest that mobility is driven by a complex interplay of multiple forces. For examples: the negative effect of tenure on mobility of all kinds is consistent both with job matching models (e.g., Jovanovic, 1979) and with survivor bias caused by unobserved heterogeneity across individuals in the propensity to move; the initially positive impact of age on business creation might reflect the effect of wealth constraints that are relaxed as an agent ages and saves, or the consequences of on-the-job learning specific to the demands of business creation; and the contrast between the effects of individual wages on entrepreneurship and self-employment recalls the mismatching model of Åstebro, Chen and Thompson (2011), in which business creation is more likely among agents with especially high and especially low ability.

\footnotetext{
${ }^{18}$ Although the positive coefficients on the quadratic terms indicate a non-monotonic effect of tenure, the turning points are at tenure levels greater than most of our sample observations.

${ }^{19}$ Education is on a scale from 1-6 corresponding to: 6. Postgraduate education; 5. Post-secondary education, two years or longer; 4 . Post-secondary education, less than two years; 3 . Upper secondary education; 2. Primary and lower secondary education; 9 or 10 years; and 1. Primary and lower secondary education, less than 9 years.
} 
Table 7

Worker Transitions. Multinomial Logit Estimation

\begin{tabular}{|c|c|c|c|}
\hline & $\begin{array}{c}\text { Entrepreneurship } \\
(1)\end{array}$ & $\begin{array}{c}\text { Self-employment } \\
(2)\end{array}$ & $\begin{array}{l}\text { Other firm } \\
\text { (3) }\end{array}$ \\
\hline \multirow[t]{2}{*}{ Firm layers: 3} & $-0.729 * * *$ & $-0.541^{* * *}$ & $-0.151^{* * *}$ \\
\hline & $(0.0454)$ & $(0.0275)$ & $(0.0461)$ \\
\hline \multirow[t]{2}{*}{ Firm layers: 4} & $-1.071^{* * *}$ & $-0.714^{* * *}$ & $-0.289 * * *$ \\
\hline & $(0.0493)$ & $(0.0334)$ & $(0.0476)$ \\
\hline \multirow[t]{2}{*}{ CEOs and Directors } & $1.420^{* * *}$ & $0.363^{* * *}$ & 0.0202 \\
\hline & $(0.0727)$ & $(0.0486)$ & $(0.0504)$ \\
\hline \multirow[t]{2}{*}{ Senior staff } & $0.988^{* * *}$ & $0.351^{* * *}$ & $0.172^{* * *}$ \\
\hline & $(0.0550)$ & $(0.0347)$ & $(0.0355)$ \\
\hline \multirow[t]{2}{*}{ Supervisors } & $0.608^{* * *}$ & $0.238^{* * *}$ & -0.00580 \\
\hline & $(0.0387)$ & $(0.0239)$ & $(0.0515)$ \\
\hline \multirow[t]{2}{*}{ Firm size } & $-9.29 \mathrm{e}-05^{* * *}$ & $-7.35 \mathrm{e}-05^{* * *}$ & $-2.75 e-05$ \\
\hline & $(1.20 \mathrm{e}-05)$ & $(8.54 \mathrm{e}-06)$ & $(1.87 \mathrm{e}-05)$ \\
\hline \multirow[t]{2}{*}{ Firm size squared } & $1.78 \mathrm{e}-09^{* * *}$ & $1.36 \mathrm{e}-09 * * *$ & $4.95 \mathrm{e}-10$ \\
\hline & $(2.35 \mathrm{e}-10)$ & $(1.72 \mathrm{e}-10)$ & $(3.40 \mathrm{e}-10)$ \\
\hline \multirow[t]{2}{*}{ Firm age } & -0.00253 & $-0.00372^{* *}$ & -0.00260 \\
\hline & $(0.00260)$ & $(0.00179)$ & $(0.00353)$ \\
\hline \multirow[t]{2}{*}{ Firm age squared } & $-5.56 e-06$ & $5.71 \mathrm{e}-06$ & $1.86 \mathrm{e}-06$ \\
\hline & $(2.52 \mathrm{e}-05)$ & $(1.66 \mathrm{e}-05)$ & $(3.12 \mathrm{e}-05)$ \\
\hline \multirow[t]{2}{*}{ Age (years) } & $0.113^{* * *}$ & $0.110^{* * *}$ & $-0.0446^{* * *}$ \\
\hline & $(0.0106)$ & $(0.00482)$ & $(0.00312)$ \\
\hline \multirow[t]{2}{*}{ Age squared } & $-0.00148^{* * *}$ & $-0.00112^{* * *}$ & $0.000316^{* * *}$ \\
\hline & $(0.000126)$ & $(5.87 e-05)$ & $(3.85 e-05)$ \\
\hline \multirow[t]{2}{*}{ Female } & $-0.862^{* * *}$ & $-0.762^{* * *}$ & $-0.124^{* * *}$ \\
\hline & $(0.0311)$ & $(0.0158)$ & $(0.0166)$ \\
\hline \multirow[t]{2}{*}{ Education } & 0.0214 & $0.0704^{* * *}$ & $0.0759 * * *$ \\
\hline & $(0.0151)$ & $(0.00844)$ & $(0.00931)$ \\
\hline \multirow[t]{2}{*}{ Log(labor income) } & $0.504^{* * *}$ & $-0.735^{* * *}$ & $-0.158^{* * *}$ \\
\hline & $(0.0372)$ & $(0.0128)$ & $(0.0172)$ \\
\hline \multirow[t]{2}{*}{ Tenure (years) } & $-0.129 * * *$ & $-0.189 * * *$ & $-0.185^{* * *}$ \\
\hline & $(0.00901)$ & $(0.00557)$ & $(0.0159)$ \\
\hline \multirow[t]{2}{*}{ Tenure squared } & $0.00303^{* * *}$ & $0.00655^{* * *}$ & $0.00726^{* * *}$ \\
\hline & $(0.000613)$ & $(0.000336)$ & $(0.000721)$ \\
\hline \multirow[t]{2}{*}{ 3yr wage growth } & $-0.384 * * *$ & $0.0562^{* * *}$ & $-0.0415^{* * *}$ \\
\hline & $(0.0278)$ & $(0.00933)$ & $(0.0136)$ \\
\hline
\end{tabular}

$N=16,485,527$. Standard errors in parentheses.

${ }^{* * *} \mathrm{p}<0.01,{ }^{* *} \mathrm{p}<0.05,{ }^{*} \mathrm{p}<0.1$. Regressions include industry, region, and year fixed effects, and dummies indicating whether firm age and employee tenure are truncated. 


\subsection{Hierarchies and mobility}

We turn now to consideration of the main effects of rank and layers on mobility. Consider first the effect of layers in Table 7; two-layer firms constitute the omitted category. Even though we condition on firm size and age, and employee rank, more layers are strongly associated with less mobility of all kinds (controlling for firm size using dummy variables for various size classes does not change these results.) Business creation rates, especially in entrepreneurship, are highly sensitive to the number of layers. For example, moving from two to three layers reduces the likelihood of a transition to entrepreneurship by 52 percent, and the likelihood of a transition to self-employment by 42 percent (see Figure 1). The effect of layers on movement to other incumbent firms, while statistically significant, is smaller in magnitude than their effect on business creation rates: each additional layer reduces the odds of job switching relative to remaining with the firm by about 18 percent.

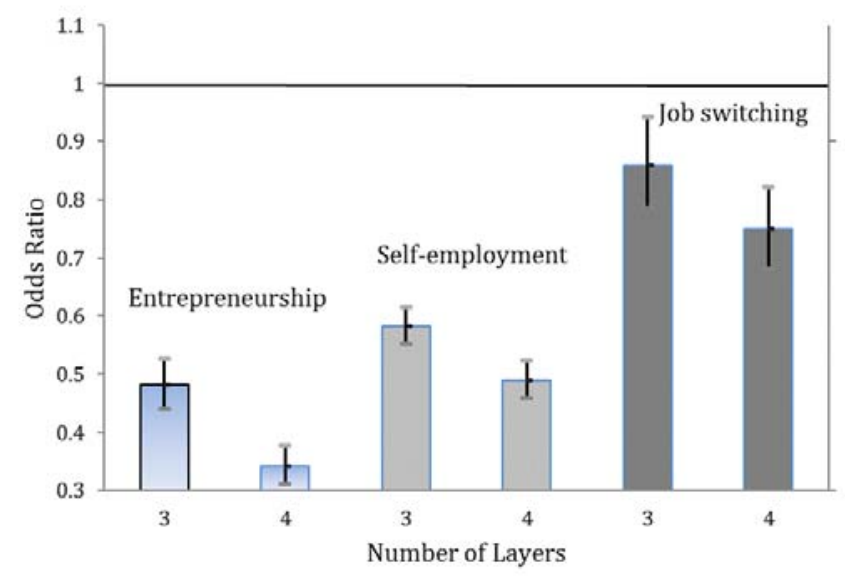

Figure 1. Odds ratios of mobility, relative to two-layer firms, by destination and number of layers, with 95\% confidence intervals. From estimates in Table 7.

Consider next the role of rank. Employees in supervisory positions are much more likely than production workers (the omitted category) to enter entrepreneurship, and the propensity to do so rises with each increase in rank. CEOs, directors and senior staff are three to four times more likely than production workers to found a limited liability company, while supervisors are twice as likely to do so (Figure 2 plots the odds ratios). Senior staff and workers with supervisory rank are also more likely to enter self-employment. The effects are smaller than for entrepreneurship, however. Finally, CEOs and Directors, and Supervisors, are no less likely to switch employers than are production workers, while Senior Staff are only a little more likely to do so. The large effect of rank on entrepreneurship is especially noteworthy, and will be relevant in Section 4 for our 
examination of competing explanations for the effect of layers on entrepreneurship.

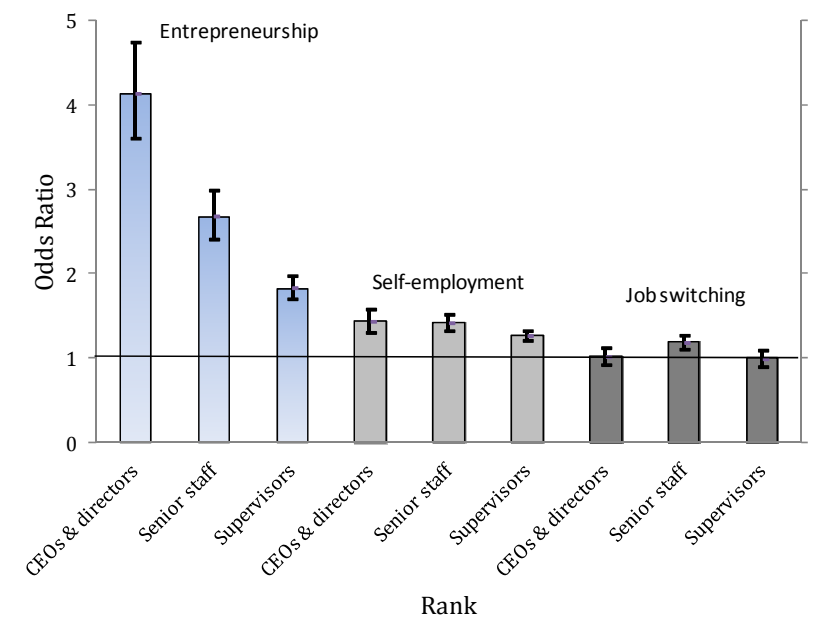

Figure 2. Odds ratios of mobility relative to production workers, by destination and rank, with 95\% confidence intervals. From estimates in Table 7.

In model A of Table 8 we add as a regressor the average span of control in the firm. Conditional on firm size, there is by construction a negative (albeit nonlinear) relationship between the average span of control and the number of layers. However, as Table 8 shows, the addition of this variable induces no changes in the estimated coefficients on layers. Moreover, the effects of changes in the span of control are very small: for example, a one standard deviation increase in the span of control is associated with only a one percent decline in the odds of entrepreneurship. The results clearly show that the number of layers is a much better predictor of mobility than is the span of control.

Because self-employment and entrepreneurship are likely strong substitutes among those considering separation from their employer, it is useful to verify the robustness of our results by restricting the choice set. We do so by examining the odds of self-employment and entrepreneurship relative to job switching after limiting the sample to movers. Model B of Table 8 reports estimates of multinomial logit estimation on this restricted sample; the baseline category is moving to an incumbent firm..$^{20}$ The results clearly

${ }^{20}$ If we were to re-estimate model A of Table 8 using moving to another firm as the baseline, it would of course be possible to formally test the IIA assumption using the Hausman-McFadden (1984) test. If the results in model A are robust, we should find that the differences between any coefficient on entrepreneurship or self-employment and the corresponding coefficient on movement to another employer in model A are similar to the corresponding coefficient on entrepreneurship or self-employment in model B. The results meet this expectation. 
demonstrate an effect of hierarchies on business creation: among movers, and conditional on firm size, firm age, span of control, and rank, the likelihood of business creation declines markedly as the number of layers increases. As already noted, the effect of layers is greater for entrepreneurship than for self-employment, and in the latter case much of the effect is due to the contrast in self-employment entry rates between firms with two layers and those with more than two.

Table 8

Worker Transitions. Multinomial Logit Estimation

\begin{tabular}{|c|c|c|c|c|c|}
\hline & \multicolumn{3}{|c|}{$\begin{array}{c}\text { Model A } \\
\text { All workers }\end{array}$} & \multicolumn{2}{|c|}{$\begin{array}{c}\text { Model B } \\
\text { Movers only }\end{array}$} \\
\hline & $\begin{array}{c}\text { Entrepreneur- } \\
\text { ship } \\
\text { (1) }\end{array}$ & $\begin{array}{l}\text { Self-employ- } \\
\text { ment } \\
(2)\end{array}$ & $\begin{array}{c}\text { Other firm } \\
\text { (3) }\end{array}$ & $\begin{array}{l}\text { Entrepre- } \\
\text { neurship } \\
(4)\end{array}$ & $\begin{array}{l}\text { Self-employ- } \\
\text { ment } \\
(5)\end{array}$ \\
\hline Firm layers: 3 & $\begin{array}{l}-0.726^{* * *} \\
(0.0455)\end{array}$ & $\begin{array}{l}-0.539^{* * *} \\
(0.0272)\end{array}$ & $\begin{array}{c}-0.134^{* * *} \\
(0.0450)\end{array}$ & $\begin{array}{l}-0.624^{* * * *} \\
(0.0516)\end{array}$ & $\begin{array}{l}-0.419^{* * *} \\
(0.0361)\end{array}$ \\
\hline Firm layers: 4 & $\begin{array}{c}-1.073^{* * *} \\
(0.0494)\end{array}$ & $\begin{array}{c}-0.724^{* * *} \\
(0.0336)\end{array}$ & $\begin{array}{c}-0.243^{* * *} \\
(0.0478)\end{array}$ & $\begin{array}{l}-0.854^{* * *} \\
(0.0528)\end{array}$ & $\begin{array}{l}-0.474^{* * *} \\
(0.0421)\end{array}$ \\
\hline Span of control & $\begin{array}{c}-0.000358 \\
(0.000414)\end{array}$ & $\begin{array}{c}-0.000960^{* * *} \\
(0.000291)\end{array}$ & $\begin{array}{l}0.00112^{* * *} \\
(0.000416)\end{array}$ & $\begin{array}{l}-0.00197^{* *} \\
(0.000980)\end{array}$ & $\begin{array}{c}-0.00354^{* * *} \\
(0.000958)\end{array}$ \\
\hline
\end{tabular}

Model A: $N=16,485,527$. Model B: $N=1,606,460$. Standard errors in parentheses.

${ }^{* * *} \mathrm{p}<0.01,{ }^{* *} \mathrm{p}<0.05,{ }^{*} \mathrm{p}<0.1$. Additional regressors, not reported, are the same as in Table 7.

\subsection{Causal inference}

While the regressions so far show convincing correlations between the number of hierarchical levels and the entrepreneurial proclivities of employees, the regressions are descriptive and resist causal interpretation. In the remainder of this section we will address whether it is possible to infer a causal effect of the hierarchy on the probability that employees leave to start a new business. This analysis is necessarily limited by the way the data on hierarchies was collected and by our ability to collect data on a plausible exogenous shock to firms' hierarchies. Nevertheless, we will make some headway that will show instrumental variable regressions consistent with the results presented so far.

To create an instrument for the number of hierarchical levels in a firm we draw on Friedrich (2015) who studies how international trade shocks affect wage inequality by changes to the hierarchy of the firm. Friedrich (2015) uses the same measure of hierarchies as Caliendo et al. (2015) and borrows the methodology of Hummels et al. (2014) to construct a firm-specific trade shock that affects the hierarchical structure of the firm. In line with this prior work we claim that an international trade shock will affect the hierarchical structure of the firms in the same way modeled and tested by Caliendo et al. (2015) but will not, at least not in the short-run, affect the probability that an em- 
ployee leaves the firm to start a new business. This is because first, engaging in international trade is a rare activity. For example, of the 5.5 million firms operating in the United States in 2000, just 4 percent were exporters. Second, exporting is done primarily by large firms. Among exporting firms, the top 10 percent accounted for 96 percent of total U.S. exports (Bernard et al., 2007.) In particular, exporting firms have 229 percent more employees than non-exporters (Bernard et al., 2007.) Small and new firms typically do not immediately export their goods, and those that do are nevertheless not the type of firms that typically react to exogenous trade shocks, but rather export directly because the product-market for that good happens to be foreign. We thus claim that foreign trade shocks are plausibly exogenous to the extensive margin of entrepreneurship.

We follow Friedrich (2015) and Hummels et al (2014), which defines an algorithm for computing exogenous trade shocks to firms using global UN Comtrade data. We do not have access to firm-level trade data as Friedrich (2015) and Hummels et al (2014) did, so instead we generate exogenous trade shocks to four digit industries, which we have available in our data. ${ }^{21}$ The aggregation of product trade data to industries will introduce noise and attenuate our coefficient estimates. However, the median number of firms per 4-digit industry is 17 in our sample, so the level of aggregation by industry may be low enough to identify a reasonable trade shock for a given firm. We define

$$
W I D_{j t}=\sum_{k} \sum_{c} s_{j c k} W I D_{c k t},
$$

where WID is World Import Demand, with $j=$ industry, $t=$ time, $k=$ product, and $c=$ country. We calculate the weighting variable $s_{j c k}$ as exports to country $x$ from Swedish industry $y$ of product $k$, weighted by all exports in Swedish industry $y$.

An important issue with aggregating trade shocks is the choice of weights. Trade shares for different product-destination pairs will vary over time in response to current market conditions. In order to address this endogeneity issue, we follow Friedrich (2015) and Hummels et al. (2014) and use industry $j$ 's trade shares in years before the beginning of the sample for $s_{j c k}$. Note that introducing new products or selling old products to new destination countries will have no effect on the trade shock instrument for a given in-

\footnotetext{
${ }^{21}$ Linking trade data for product codes HS96 to Swedish 4-digit SNI 2002 industry codes is complicated by the fact that the links are not always unique. First, $0.2 \%$ of the links between HS96 product codes and CPC1 product categories are one-to-many links. Second, $24 \%$ of the links between CPC1 product groups and ISI Rev 3 industries are one-to-many links, and a further $7 \%$ are one-to-many links between ISI Rev 3 industries to ISI Rev 3.1 industries. Finally, as much as $43 \%$ are one-to-many links between ISIC Rev 3.1 and NACE Rev 1.1 (which equals SNI 2002 available in our data). We randomly allocate products to industries and industries to industries when there are one-to-many links. We have run robustness checks where we repeat the randomization for different seeds and our results remain the same. In general the random allocation will drag down coefficient estimates towards zero by introducing white noise in estimations.
} 
dustry, and thus alleviates concerns that the instrument is not exogenous to entrepreneurship. We compute $s_{j c k}$ for the pre-sample years 1996 to 2000 and take the average weight over these years.

We cannot run our preferred maximum likelihood multinomial choice models as IV regressions are not defined under such conditions. Instead we run linear probability OLS regressions and then IV 2SLS regressions to show that flatter firms spawn more entrepreneurs. For the purpose of the IV analysis we create a LHS variable $=1$ for movers to entrepreneurship or self-employment, else zero, and a semi-continuous RHS variable reflecting the number of firm layers. We include all control variables presented in Table 8 , Model A but do not report them. The main results from the analysis are presented in Table 9. The OLS regression in column 1 reports a negative correlation between the number of layers in a firm and the linear probability estimate of moving. However, the correlation disappears in the IV regression as the endogenous variable is not sufficiently identified in first stage of the IV model. There is evidently a lot of noise in the estimates, which is understandable given four features of our data (two which are different than in Caliendo et al., 2015):

1. Our firm-level data on hierarchies is only sampled every fifth year for most firms and since we have eight years of data, the average number of observations per firm is only 1.9, making identification based on changes in hierarchies over time for a given firm difficult. The cross-sectional identification does not suffer from the same difficulty as we have plenty of firms in the dataset.

2. We do not have firm-level data on product trade, but industry data. The mapping procedure from product trade to industry to impact on firms as outlined above suffer from the introduction of noise.

3. The IV procedure by necessity of linearization groups entry into entrepreneurship of two kinds together where we in MNL analysis detected significant differences between them, and also groups movers to other firms with stayers, also introducing potential aggregation bias.

4. We have missing data on the trade shocks for a fairly large number of observations because these firms are in four digit industries that did not engage in international trade during our sample period. While we have cross-sectional data on hierarchies for 128,262 firms, we only have trade shock data for 18,266 firms.

We can make some further headway by changing the level of analysis. In particular, it is plausible to look at changes at the firm level since the trade shock occurs at the firmlevel not at the employee level. The associated change in the number of layers is also at the firm level. Responses to these changes are of course by individuals. However, a larger firm has more employees than a smaller firm, and we currently record the contribution to the average estimated effect of the change in the hierarchy at a given firm by the number of employees in that firm, putting much more weight in the average estimate for changes in larger than smaller firms. We do the aggregation to firm-level analysis in two ways. 
We first run the regressions at the firm level taking as the dependent variable the fraction of employees that depart for entrepreneurship or self-employment, clustering the standard errors at the firm level to control for repeated observations in a firm over time. To obtain other controls, we similarly form means for the firm of our individual level variables, while leaving out an individual's position in the hierarchy and the firm age truncation dummy. Results are reported in Columns 3 and 4. Notice that the IV regression produces a coefficient estimate that is approximately eight times larger in magnitude than in the OLS regression.

An alternative way of doing the firm-level analysis is to weight each individual observation by the inverse of the number of employees in each firm. Results from this approach are reported in Columns 5 and 6 of Table 9. The first-stage identification of the endogenous variables is now somewhat stronger, as is the $2^{\text {nd }}$ stage effect. As a test of the vagaries of linearizing and collapsing the outcome variable for the purposes of IV analysis, we rerun the regression reported in column 6 but only for movers, comparing the probability of becoming either an entrepreneur or self-employed (collapsed) with moving to another established firm. The equivalent analysis in the multinomial framework was presented in Table 8, model B. This removes one of the problems where we collapse both those staying and those moving to another firm into the intercept. Results are reported in Column 7. Results are consistent in the sign, but with a much larger coefficient for the effect of hierarchies on entrepreneurship. This indicates that the remaining manipulations which we apply to data in order to fit the IV framework are still likely to be associated with bias.

A cautious conclusion might be that although suffering from several data limitations, the IV result points to a larger point estimate of the causal effect than the OLS correlational results, although with a considerable amount of noise introduced and with bias likely introduced due to the necessity of complying with IV regression conditions that may not be appropriate for the data.

\section{Explaining the Hierarchy Effect}

In the previous section we found that the number of layers within a firm is negatively correlated with mobility of all kinds. More layers appear to markedly suppress rates of business creation by employees, while the magnitude of the impact on movements to other employers is somewhat smaller. In this section we discuss two potential explanations for the correlation we find. 
Table 9

OLS and 2SLS with IV

\begin{tabular}{|c|c|c|c|c|c|c|c|}
\hline & OLS & IV 2SLS & OLS & IV 2SLS & OLS & IV 2SLS & IV 2SLS \\
\hline & 1 & 2 & 3 & 4 & 5 & 6 & 7 \\
\hline Number of layers & $-.0018^{* * *}$ & 0.002 & $-.0032 * * *$ & $-.024^{*}$ & $-.0030^{* * *}$ & $-.020^{* *}$ & $-.111^{*}$ \\
\hline $\mathrm{t}$-value & -25.33 & 0.50 & -18.36 & -1.80 & -21.24 & -1.98 & -1.80 \\
\hline \multicolumn{8}{|l|}{ 1st stage equation } \\
\hline World import demand & & 0.000009 & & $.000015^{* *}$ & & $.000018^{* * *}$ & $0.00002^{* * *}$ \\
\hline F-value & & 1.33 & & 5.47 & & 6.86 & 8.04 \\
\hline \multirow{2}{*}{$\begin{array}{c}\text { Number of obs.: individual-year } \\
\text { firms } \\
\end{array}$} & $16,485,527$ & $2,404,659$ & n.a & n.a & $16,485,527$ & $2,404,659$ & 239,311 \\
\hline & 128,062 & 18,266 & 243,689 & 18,266 & 128,062 & 18,266 & 10,249 \\
\hline
\end{tabular}

*** $\mathrm{p}<0.01,{ }^{* *} \mathrm{p}<0.05, * \mathrm{p}<0.1$. Regressions are linear probability models of whether an employee becomes an entrepreneur or self-employed ( $=1$ ), compared to staying employed or moving to another established firm (=0). IV results are based on joint simultaneous estimation of stage 1 and 2 equations. Regressions include a constant term, and controls for rank, labour income, past wage growth, age, age squared, gender, education, tenure, tenure squared, firm age, firm size, span of control, industry, region, and year dummies, and dummies indicating whether firm age and employee tenure are truncated. For columns 3 and 4 we form firm-level averages from employee data and drop rank and the dummy indicating whether employee tenure are truncated. For columns 5 and 6 we weight each individual-year observation with the inverse of the number of employees in the firm. For column 7 we run regression as in 6 , but compare movers becoming an entrepreneur or self-employed $(=1)$, to those moving to an established firm $(=0)$. Those remaining in the firm are dropped. 


\subsection{Preference sorting}

Ever since the industrial revolution and the subsequent work by Frederick Taylor, Henry Ford, Max Weber and Henry Fayol, modern bureaucracies have been created to improve efficiency through the division of labor, strict reporting relationships, and the institutionalization of hierarchies to support efficient task execution and decision making. However, bureaucracies with precisely defined tasks, strict managerial control, and concomitantly tall hierarchies often reduce the possibilities for employees to perform varied work or to easily change between different jobs within the firm. Such features of organizations may therefore lead people with an aversion to jobs with monotonous tasks and strict rules to select away from organizations containing such jobs. Instead, smaller firms with flatter hierarchies and more flexible procedures and tasks may offer people greater job satisfaction. Indeed, empirical research has shown that a) individuals are more satisfied at work with more flexible and varied job tasks (Walker and Guest, 1952; Hackman and Oldham, 1976; Rousseau, 1977); b) smaller firms offer both greater work variety and job satisfaction (Carter and Keon, 1986; Benz and Frey, 2008a; Elfenbein et al., 2010); c) job satisfaction is greater in less bureaucratic firms (Arches, 1991; Finlay et al., 1995).

While bureaucratic organizations might induce changes in their employees (for example, they might cause employees to become less innovative or they may more easily seed the roots of disagreement with fellow workers or managers) we focus our attention here on selection. It is not difficult to imagine that individuals who dislike bureaucracy are more likely to choose to work in smaller, flatter, and less bureaucratic firms, and also more likely to choose to become entrepreneurs.

In favor of the argument that there is a preference for entrepreneurship stemming from dissatisfaction with wage work, it is well documented that across a wide range of countries, self-employed are more satisfied with their work than wage workers (Taylor, 1996; Blanchflower and Oswald, 1998; Blanchflower, 2000; Hundley, 2001a; Prottas and Thompson, 2006; Benz and Frey, 2008a, 2008b; Kawaguchi, 2008; Fuchs-Schundeln, 2009).22 Moreover, the self-employed report they are more satisfied with their jobs because their work provides more autonomy, flexibility, and skill utilization (Hundley, 2001; Prottas and Thompson, 2006; Benz and Frey, 2008b). These underlying mechanisms have been stable over the past thirty years and are not due simply to personality differences. However, the job satisfaction advantage to self-employment is relatively small or nonexistent compared

\footnotetext{
${ }^{22}$ Using the unification of East and West Germany as a natural experiment, Benz and Frey (2008a) further show that this result is not due to reverse causation (i.e., it is not the case that more happy people enter entrepreneurship).
} 
to managers and members of the established professions, occupations where workers have relatively high autonomy and skill utilization (Hundley, 2001), and the advantage is larger when compared against wage earners working in larger organizations (Benz and Frey, 2008a), suggesting that what people really dislike about wage work is bureaucracy.

Finally, there is an extensive literature documenting that some individuals declare, often at an early stage in their career, a preference to create and operate their own business, and that such declarations predict entry into entrepreneurship (Hamilton, 2000; Halaby, 2003; Benz and Frey, 2008a; Åstebro and Thompson, 2011). Such preferences may be shaped already when young. For example, Halaby (2003) and Sørensen (2007) show that the offspring of self-employed parents, who have on average much greater entrepreneurial aspirations than the offspring of wage earners, are more likely to work in smaller and presumably less bureaucratic organizations. Furthermore, another strand of literature documents that engaging in wage work with a lot of task variety is strongly associated with a higher probability of becoming an entrepreneur (Lazear, 2005; Elfenbein et al., 2010; Åstebro and Thompson, 2011). Taking all this literature together, there seems therefore to be an association between the preferences of people who found businesses and the propensity to work in less hierarchical organizations.

Preference sorting predicts that individuals working in small firms, younger firms and, in particular, firms with flatter hierarchies would be more likely to become entrepreneurs since people that dislike bureaucracy would be more likely to sort into both these types of employment. The hypothesis also generates several predictions that are potentially discriminating. First, it predicts that those with a higher rank in an organization will be less likely to leave for entrepreneurship as they are more likely to enjoy wage work. Second, it has implications for how well people do in entrepreneurship after leaving an established firm. Agents create and then continue to operate businesses if the total compensation expected from the business exceeds the foregone wage. However, total compensation from entrepreneurship and self-employment includes a non-pecuniary component among those with a preference for entrepreneurship, and this will induce them to create businesses even if they are likely to yield only modest monetary returns. And to continue operating those businesses longer than would someone without non-pecuniary benefits. Because people with such preferences are presumably overrepresented in smaller and less-bureaucratic firms, we may therefore anticipate either or both of (i) a positive relationship between the number of layers and subsequent monetary performance in entrepreneurship, and (ii) a negative relationship between the number of layers and the likelihood of business survival. Similarly, we may anticipate either or both of (iii) a positive relationship between firm size and subsequent monetary performance in entrepreneurship, and (iv) a negative relationship between the firm size and the likelihood of business survival. 


\subsection{Ability sorting}

In a well-known study, Lazear (2005) proposes that entrepreneurs are Jacks of all trades whose diverse skills enable them to carry out the varied tasks involved in the creation of a successful business. He conjectures that individuals can invest in the accumulation of diverse skills through education or on-the-job training. Individuals who intend to pursue an entrepreneurial career choose to learn a variety of skills, either by pursuing a varied curriculum in college, by accepting a variety of positions in work or by working in firms in which a variety of activities need to be undertaken by each employee. Lazear provides supporting evidence from the work histories and university transcripts of Stanford MBA alumni, while others have found supporting evidence in diverse and more representative data sets (e.g., Wagner, 2003, 2006; Silva, 2007; Åstebro, Chen and Thompson, 2011; and Chen and Thompson, 2016).

To link Lazear's theory to the hierarchical structure of firms, we consider a variation on Caliendo and Rossi-Hansberg's (2012) model of hierarchy, in which output is secured by solving problems, and worker knowledge and time are key inputs into the production process. Workers on the shop floor (their context is manufacturing) produce by solving problems that present themselves. If they have the knowledge, they solve the problem themselves, which yields some output. If they do not have the knowledge they pass the problem up to their supervisor, who may either solve the problem or pass it up to the next layer of management. Employees are constrained not only by their knowledge, but also by time. Thus, a supervisor in charge of too many workers, or of workers with too little knowledge, will not be able to address all the problems that come up the line.

Suppose that problems can be indexed on the line, with the most common problems being assigned a lower index. Figure 3 illustrates a firm with three layers, the arrows indicating the range of problems each type of worker is able to solve. ${ }^{23}$ In each unit of time, a production worker receives a draw, $\zeta$, of a problem. If $\zeta \in\left[0, z_{1}\right]$, the production worker solves the problem himself and produces a fixed output. However, if $\zeta>z_{1}$, the production worker knows only that he cannot solve the problem and turns to his immediate supervisor for help, who solves it if $\zeta \in\left[z_{1}, z_{2}\right]$ and passes it up to the CEO for a solution if $\zeta>z_{2}$. Helping pro-

\footnotetext{
${ }^{23}$ In Caliendo and Rossi-Hansberg's model there is no overlap in the knowledge sets of each rank, but consistency with Lazear's theory demands that workers in higher layers are at least familiar with the simpler problems faced by workers in lower layers. However, Garicano (2000, Section IV) develops a model similar to Caliendo and Rossi-Hansberg's and shows that the characteristics of the optimal organization design remain similar when the knowledge sets of workers at higher layers include the knowledge sets at lower layers.
} 
duction workers takes time, $h$, so in each unit of time a manager can only solve $1 / h$ problems. Let $f(\zeta)$ denote the frequency with which problem $\zeta$ arises, and let $F(\zeta)$ be the corresponding distribution. With $n_{1}$ production workers, the expected number of problems brought to the attention of the supervisor in each period is $n_{1}\left(1-F\left(z_{1}\right)\right)$, of which $n_{1}\left(1-F\left(z_{2}\right)\right)$ will have to be passed up to the CEO.

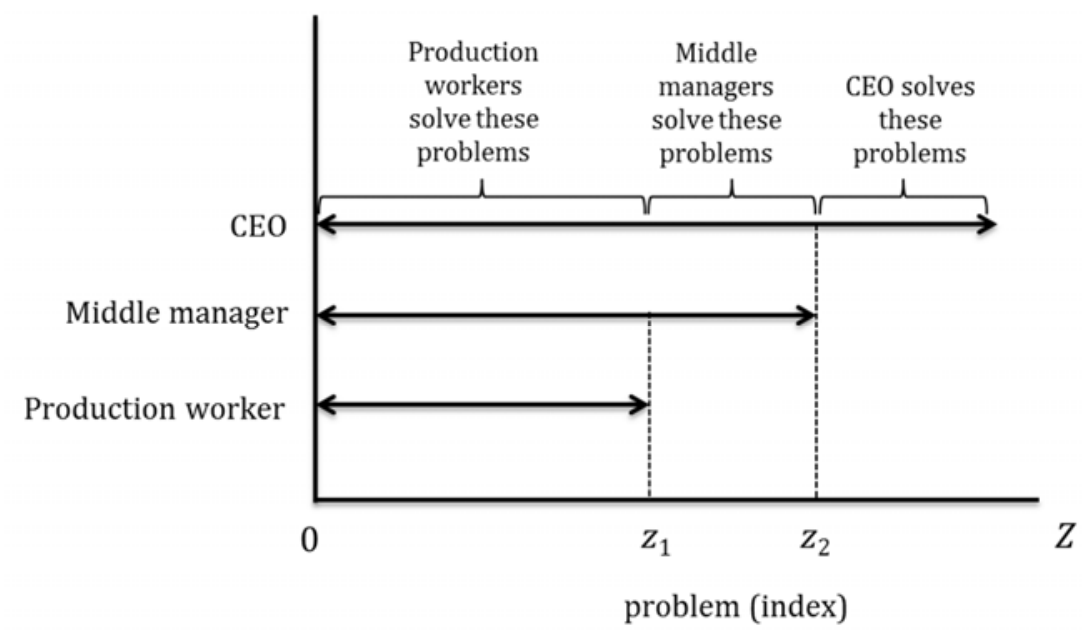

Figure 3

It is now easy to see the firm's potential responses to an increase in the number of production workers induced, say, by an exogenous increase in demand. If nothing changes in Figure 3 , middle managers are likely to be overwhelmed with problems they have no time to address. So a first possibility is that the firm increases the number of middle managers to match the increase in the number of production workers. However, this can only offer a partial solution, because the single CEO will also become overwhelmed with the demands on his time. In response, the firm must increase $z_{2}$, so that a smaller fraction of problems are passed to the top of the chain. This requires hiring middle managers with a greater span of knowledge. In their model, Caliendo and Rossi-Hansberg (2012) show that when a firm increases size without adding a layer, it increases both $z_{1}$ and $z_{2}$, hiring more qualified workers at a higher wage at every level below the CEO. Alternatively, the firm could add a layer. Caliendo and Rossi-Hansberg (2012) show that, when a firm expands layers, it increases the number of workers at each pre-existing layer. The additional layers enable workers to pass more problems up the line. They therefore need less knowledge and the average wage declines. Caliendo, et al. (2015) exhaustively examine these predictions of the model using a 
panel of observations on the large majority of French manufacturing firms, and find no instance in which the evidence contradicts the predictions. Tåg (2013) replicates parts of their study and concludes that the predictions of Caliendo and Rossi-Hansberg (2012) also hold for Swedish manufacturing firms.

Our rendering of the information-processing story, in which workers at higher ranks know how to solve problems that those at lower ranks can solve, predicts that conditional on firm size firms with fewer layers employ workers with the ability to solve a broader range of problems. Similarly, conditional on the number of layers, larger firms are more likely to have employees with broad skill sets. Following Lazear (2005), such workers are more likely to enter entrepreneurship and self-employment, and they are likely to perform better when they do. Ability sorting therefore predicts a negative effect of more layers, and a positive effect of firm size, on the rate of entrepreneurship, on business earnings among entrepreneurs, and on business survival. The two explanations -- sorting by preference and sorting by ability -- also have discriminating predictions for the effect of rank on entry into entrepreneurship: while preference selection indicates that employees at higher rank are less likely to found a business because they find their job more satisfying, information processing suggests that higher rank induces entrepreneurship because such employees have a broader range of skills.

Table 10 summarizes the predictions of the two models, alongside the results that are reported below. H1 simply notes that both models predict the key finding documented in Section 3. $\mathrm{H} 2$ and $\mathrm{H} 3$, which relate firm size and individual rank to entrepreneurship rates, are discriminating predictions, as are $\mathrm{H} 4$ (relating layers to business earnings) and H7 (relating firm size to business survival).

Table 10

Predicted and Observed Correlations

\begin{tabular}{lccc}
\hline \hline & $\begin{array}{c}\text { Preference } \\
\text { sorting }\end{array}$ & $\begin{array}{c}\text { Information } \\
\text { processing }\end{array}$ & Results \\
\hline H1. Number of layers v. entrepreneurship & - & - & - \\
H2. Firm size v. entrepreneurship & - & + & - \\
H3. Rank v. entrepreneurship & - & + & + \\
H4. Number of layers v. business earnings & + & - & 0 \\
H5. Number of layers v. business survival & - & - & - \\
H6. Firm size v. business earnings & + & + & + \\
H7. Firm size v. business survival & - & + & - \\
\hline \hline
\end{tabular}




\subsection{Evidence}

The results reported in Table 7 provides unambiguous evidence on $\mathrm{H} 2$ and $\mathrm{H} 3$. First, larger firms are associated with lower rates of entry into business creation, consistent with the preference sorting model. Second, individuals at higher ranks are much more likely to become entrepreneurs than are those at lower ranks, providing support for ability sorting.

To test $\mathrm{H} 4$ through $\mathrm{H} 7$, we regress entrepreneurial and self-employment earnings and survival rates two years after business creation on the number of layers in the business owner's previous employer. We run regressions including controls for wages, and this inclusion merits some commentary. In Caliendo and Rossi-Hansberg (2015), a worker's wage is a sufficient statistic for his skill, so that layers and firm size should not matter once one controls for earnings. In practice, however, wages are a crude proxy for skill - because of the difficulties firms have in measuring an individual's skill level and because of labor market search frictions that induce wage dispersion among otherwise identical individuals. We anticipate, then, that layers and firm size should continue to matter in the information processing story, even with the inclusion of the wage control. Moreover, as the wage also measures the opportunity cost of entrepreneurship and is correlated with firm size and layers, excluding it is problematic.

We report the results of these regressions, separately for entrepreneurs and the self-employed, in Table $11 .{ }^{24}$ Our findings are mixed. First, we find no relationship between the number of layers in the previous employer and an agent's earnings from entrepreneurship or self-employment. However, firm size is positively related to earnings, consistent with ability sorting. Second, we find a negative association between survival and layers, and between survival and firm size; the former result is consistent with both sorting mechanisms, but the latter is inconsistent with the ability sorting.

Of course, preference and ability sorting are not mutually exclusive processes, so it is quite possible that the evidence confounds contributions from both sorting mechanisms. We can, however, conduct a sharper test of the information processing model. So far, we have controlled in our multinomial logit regressions for rank, the number of layers and firm size. Of particular note here is the positive effect we found of higher rank on the likelihood of business creation, and especially of entrepreneurship. However, the meaning of a particular rank depends on the hierarchical structure of the firm. The information processing story implies that the more layers there are in a firm the greater the difference between the

\footnotetext{
${ }^{24}$ Results reported in the appendix show that these results hold if we examine performance four years after business creation. Span of control is not included as there is no clear prediction emanating from this construct. However, including it does not change our results.
} 
breadth of knowledge of employees in the highest and lowest ranks. As a result, the likelihood of business creation of any rank relative to the lowest rank in the firm should be greater the more ranks that lie between them.

Table 11

Performance of entrepreneurs, two years after business creation

\begin{tabular}{|c|c|c|c|c|}
\hline & \multicolumn{4}{|c|}{ OLS Regressions } \\
\hline & \multicolumn{2}{|c|}{ Log(Total income) } & \multicolumn{2}{|c|}{ Survival } \\
\hline & $\begin{array}{c}\text { Entrepreneurs } \\
\text { (1) }\end{array}$ & $\begin{array}{c}\text { Self-employed } \\
\text { (2) }\end{array}$ & $\begin{array}{c}\text { Entrepreneurs } \\
\text { (3) }\end{array}$ & $\begin{array}{c}\text { Self-employed } \\
(4)\end{array}$ \\
\hline \multirow[t]{2}{*}{ Firm layers: 3} & 0.0102 & -0.0521 & -0.0236 & $-0.0429^{* * *}$ \\
\hline & $(0.0218)$ & $(0.0580)$ & $(0.0146)$ & $(0.00857)$ \\
\hline \multirow[t]{2}{*}{ Firm layers: 4} & 0.00412 & 0.0197 & $-0.0394 * * *$ & $-0.0533^{* * *}$ \\
\hline & $(0.0218)$ & $(0.0537)$ & $(0.0143)$ & $(0.00828)$ \\
\hline \multirow[t]{2}{*}{ CEOs and Directors } & $0.147^{* * *}$ & $0.834^{* * *}$ & $-0.0943^{* * *}$ & $-0.120 * * *$ \\
\hline & $(0.0445)$ & $(0.142)$ & $(0.0250)$ & $(0.0203)$ \\
\hline \multirow[t]{2}{*}{ Managers } & $0.126^{* * *}$ & 0.126 & -0.0267 & $-0.0932^{* * *}$ \\
\hline & $(0.0292)$ & $(0.106)$ & $(0.0188)$ & $(0.0144)$ \\
\hline \multirow{2}{*}{ Supervisors } & $0.0973^{* * *}$ & $0.113^{* * *}$ & -0.00372 & $-0.0396^{* * *}$ \\
\hline & $(0.0202)$ & $(0.0409)$ & $(0.0131)$ & $(0.00614)$ \\
\hline \multirow[t]{2}{*}{ Firm Size } & $2.26 \mathrm{e}-06$ & $1.36 \mathrm{e}-05^{*}$ & $-3.28 e-06$ & $-3.50 \mathrm{e}-06^{* * *}$ \\
\hline & $(4.30 \mathrm{e}-06)$ & $(7.33 \mathrm{e}-06)$ & $(2.41 \mathrm{e}-06)$ & $(1.05 \mathrm{e}-06)$ \\
\hline \multirow[t]{2}{*}{ Firm Size^^2 } & -0 & $-2.17 e-10$ & $7.72 \mathrm{e}-11^{*}$ & $6.79 \mathrm{e}-11^{* * *}$ \\
\hline & $(8.36 \mathrm{e}-11)$ & $(1.53 e-10)$ & $(0)$ & $(0)$ \\
\hline \multirow[t]{2}{*}{ Firm Age } & 0.000200 & $0.00502^{* *}$ & 0.000442 & -0.000487 \\
\hline & $(0.00106)$ & $(0.00220)$ & $(0.000719)$ & $(0.000347)$ \\
\hline \multirow[t]{2}{*}{ Firm Age $^{\wedge} 2$} & $-3.37 e-06$ & $-4.14 \mathrm{e}-05^{* *}$ & $9.19 \mathrm{e}-07$ & $6.62 \mathrm{e}-06^{* *}$ \\
\hline & $(1.06 \mathrm{e}-05)$ & $(2.07 e-05)$ & $(6.99 e-06)$ & $(3.32 \mathrm{e}-06)$ \\
\hline \multirow[t]{2}{*}{ Log(wage) } & $0.324^{* * *}$ & $0.408^{* * *}$ & $0.0500^{* * *}$ & -0.00296 \\
\hline & $(0.0203)$ & $(0.0264)$ & $(0.0104)$ & $(0.00328)$ \\
\hline \multirow[t]{2}{*}{ 3yr wage growth } & $-0.0617^{* * *}$ & $-0.175^{* * *}$ & $-0.0350 * * *$ & $-0.00937^{* * *}$ \\
\hline & $(0.0154)$ & $(0.0234)$ & $(0.00880)$ & $(0.00304)$ \\
\hline Observations & 7,094 & 12,683 & 9,627 & 45,824 \\
\hline$R$ squared & 0.206 & 0.086 & 0.046 & 0.021 \\
\hline
\end{tabular}

Standard errors in parentheses. ${ }^{* * *} \mathrm{p}<0.01,{ }^{* *} \mathrm{p}<0.05,{ }^{*} \mathrm{p}<0.1$. Regressions include a constant term, and controls for age, age squared, gender, education, tenure, tenure squared, industry, region, and year. Total income is the sum of capital and labor income accruing to the individual two years after business creation. Success is equal to one if a business created in year $t$ is active, in the sense that it has more than one employee (including the founder), two years after business creation. 
Evidence on this prediction is provided in Table 12, which estimates the effect of rank on the likelihood of business creation separately for firms with different numbers of layers. Consistent with the information processing story, we find first that for any given number of layers in a firm the probability of entering entrepreneurship is greater the higher the relative position. Moreover, the coefficients for entrepreneurship on the top layers are larger the more layers there are in the firm. This is true for employees in the top ranks as we move from two-layer to three-layer firms, and then to four-layer firms; and it is also true for employees in the second-highest rank as we move from two to three layers in the firm. These patterns for entry into entrepreneurship suggest, consistent with Caliendo and Rossi-Hansberg (2012), that the span of knowledge of managers is related to the number of layers beneath them, rather than the title of their rank. These patterns are not evident for self-employment, however, suggesting that the information processing story is relevant only for entry into entrepreneurship.

\section{Conclusions}

In this paper, we asked whether small firms are more frequent incubators of entrepreneurs because they tend to be less hierarchical. This could help improve our understanding of who becomes an entrepreneur, how firms can better retain workers, and what might drive crossfirm and cross-country differences in rates of entrepreneurship. We found that hierarchy is indeed less prevalent in small firms and is associated with more frequent transitions of employees into self-employment and entrepreneurship.

We then examined two potential mechanisms for the impact of hierarchy on business creation rates. First, individuals with a preference for entrepreneurship may choose to seek employment in firms with fewer layers (preference sorting). Second, employees in firms with fewer layers may have a broader range of skills, and this makes them more fit for entrepreneurship (ability sorting). We found evidence for both preference sorting and ability sorting. However, our strongest result, a test showing that the probability of becoming an entrepreneur clearly rises with the rank in an organization was consistent with ability sorting and inconsistent with preference sorting. Nevertheless, there remains a substantial unexplained component of the effect of layers on business creation rates and we do not claim to have uncovered a causal relationship. An appealing avenue for future theoretical and empirical work is studying more in detail the mechanisms behind this hierarchy effect and investigating to what extent it is causal.

Our analysis is based on the Swedish matched employer-employee dataset. Conventional wisdom has it that, along with other Scandinavian countries, Sweden's labor market is 
Table 12

Worker Transitions, Multinomial Logit estimations

\begin{tabular}{|c|c|c|c|c|c|c|c|c|c|}
\hline & \multicolumn{3}{|c|}{ FOUR LAYERS } & \multicolumn{3}{|c|}{ THREE LAYERS } & \multicolumn{3}{|c|}{ TWO LAYERS } \\
\hline & & Self-employ- & & & Self-employ- & & & Self-employ- & \\
\hline & Entrepreneurship & ment & Other firm & Entrepreneurship & ment & Other firm & Entrepreneurship & ment & Other firm \\
\hline \multirow[t]{2}{*}{ Top } & $1.434^{* * *}$ & $0.265^{* * *}$ & 0.0749 & $0.901^{* * *}$ & $0.431^{* * *}$ & $0.137^{* * *}$ & $0.671^{* * *}$ & $0.197^{* * *}$ & -0.0391 \\
\hline & $(0.123)$ & $(0.0684)$ & $(0.0675)$ & $(0.0962)$ & $(0.0561)$ & $(0.0417)$ & $(0.0582)$ & $(0.0323)$ & $(0.0355)$ \\
\hline \multirow[t]{2}{*}{ Second } & $1.059 * * *$ & $0.301^{* * *}$ & $0.127^{* *}$ & $0.458^{* * *}$ & $0.262^{* * *}$ & $0.105^{* * *}$ & & & \\
\hline & $(0.0757)$ & $(0.0431)$ & $(0.0495)$ & $(0.0750)$ & $(0.0361)$ & $(0.0370)$ & & & \\
\hline \multirow[t]{2}{*}{ Third } & $0.697^{* * *}$ & $0.235^{* * *}$ & -0.111 & & & & & & \\
\hline & $(0.0580)$ & $(0.0317)$ & $(0.0740)$ & & & & & & \\
\hline \multirow[t]{2}{*}{ Span of control } & -0.000994 & $-8.84 \mathrm{e}-05$ & 0.00162 & $9.77 e-05$ & $-0.00116^{* *}$ & 0.000890 & 0.000870 & 0.000346 & $0.00143^{* * *}$ \\
\hline & $(0.000764)$ & $(0.000558)$ & $(0.00121)$ & $(0.000296)$ & $(0.000463)$ & $(0.000657)$ & $(0.000743)$ & $(0.000484)$ & $(0.000463)$ \\
\hline \multirow[t]{2}{*}{ Firm Size } & $-7.51 \mathrm{e}-05^{* * *}$ & $-6.75 e-05^{* * *}$ & $-2.83 e-05$ & $-0.000292^{* * *}$ & $-0.000198^{* * *}$ & $-2.44 \mathrm{e}-05$ & $-0.00134^{*}$ & $-0.00165^{* * *}$ & $0.00116^{* *}$ \\
\hline & $(1.26 \mathrm{e}-05)$ & $(8.99 \mathrm{e}-06)$ & $(1.82 \mathrm{e}-05)$ & $(5.51 \mathrm{e}-05)$ & $(4.16 \mathrm{e}-05)$ & $(7.63 e-05)$ & $(0.000758)$ & $(0.000470)$ & $(0.000488)$ \\
\hline \multirow[t]{2}{*}{ Firm Size^^2 } & $1.42 \mathrm{e}-09^{* * *}$ & $1.24 \mathrm{e}-09^{* * *}$ & $4.91 \mathrm{e}-10$ & $1.28 \mathrm{e}-08^{* * *}$ & $9.26 \mathrm{e}-09^{* * *}$ & $-2.71 \mathrm{e}-09$ & $2.26 \mathrm{e}-07^{*}$ & $2.58 \mathrm{e}-07^{* * *}$ & $-6.08 \mathrm{e}-07^{* *}$ \\
\hline & $(2.47 \mathrm{e}-10)$ & $(1.81 \mathrm{e}-10)$ & $(3.31 \mathrm{e}-10)$ & $(3.47 \mathrm{e}-09)$ & $(2.85 \mathrm{e}-09)$ & $(4.70 \mathrm{e}-09)$ & $(1.21 \mathrm{e}-07)$ & $(7.73 e-08)$ & $(2.70 \mathrm{e}-07)$ \\
\hline \multirow[t]{2}{*}{ Firm Age } & 0.00398 & 0.000723 & -0.00192 & -0.00355 & -0.00292 & $-0.00968^{* * *}$ & $-0.0203^{* * *}$ & $-0.0148^{* * *}$ & $-0.00345^{*}$ \\
\hline & $(0.00385)$ & $(0.00259)$ & $(0.00503)$ & $(0.00397)$ & $(0.00225)$ & $(0.00321)$ & $(0.00335)$ & $(0.00184)$ & $(0.00207)$ \\
\hline \multirow[t]{2}{*}{ Firm Age ${ }^{\wedge} 2$} & $-4.95 e-05$ & $-2.09 e-05$ & $-1.10 e-06$ & $3.10 \mathrm{e}-06$ & $-1.65 e-07$ & $4.56 \mathrm{e}-05$ & $0.000128^{* * *}$ & $8.66 \mathrm{e}-05^{* * *}$ & $-2.07 e-06$ \\
\hline & $(3.56 \mathrm{e}-05)$ & $(2.23 \mathrm{e}-05)$ & $(4.16 \mathrm{e}-05)$ & $(3.97 \mathrm{e}-05)$ & $(2.21 \mathrm{e}-05)$ & (3.71e-05) & $(3.40 \mathrm{e}-05)$ & $(2.19 \mathrm{e}-05)$ & $(4.13 e-05)$ \\
\hline \multirow[t]{2}{*}{ Log(wage) } & $0.475^{* * *}$ & $-0.714^{* * *}$ & $-0.156^{* * *}$ & $0.683^{* * *}$ & $-0.794^{* * *}$ & $-0.142^{* * *}$ & $0.552^{* * *}$ & $-0.838^{* * *}$ & $-0.124^{* * *}$ \\
\hline & $(0.0536)$ & $(0.0149)$ & $(0.0227)$ & $(0.0699)$ & $(0.0204)$ & $(0.0231)$ & $(0.0687)$ & $(0.0173)$ & $(0.0173)$ \\
\hline \multirow{2}{*}{$\begin{array}{l}3 \text { yr. wage } \\
\text { growth }\end{array}$} & $-0.397^{* * *}$ & $0.0577^{* * *}$ & $-0.0393^{* *}$ & $-0.358^{* * *}$ & $0.0583^{* * *}$ & $-0.0362^{* * *}$ & $-0.414^{* * *}$ & 0.0131 & $-0.0922^{* * *}$ \\
\hline & $(0.0378)$ & $(0.0125)$ & $(0.0200)$ & $(0.0601)$ & $(0.0204)$ & $(0.0131)$ & $(0.0546)$ & $(0.0168)$ & $(0.00603)$ \\
\hline Observations & \multicolumn{3}{|c|}{$12,882,472$} & \multicolumn{3}{|c|}{$2,342,313$} & \multicolumn{3}{|c|}{$1,260,742$} \\
\hline
\end{tabular}

Standard errors in parentheses. ${ }^{* * *} \mathrm{p}<0.01,{ }^{* *} \mathrm{p}<0.05,{ }^{*} \mathrm{p}<0.1$. Regressions include controls for age, age squared, female, education, tenure, tenure squared, industry, year and region, and dummies indicating truncation of firm age and tenure variables. 
atypical. This conventional wisdom is now dated, ${ }^{25}$ and most employment data reveal that Sweden is comparable to other OECD countries. While labor mobility remains lower than the OECD average, its wage structure is now much like other high-income countries. In fact, Lazear and Shaw (2008), show that across several measures such as wage dispersion within firms, the variance of wage growth rates within firms, and even overall wage dispersion, Sweden is not remarkably different from seven other countries they study, including the U.S.A. The environment for new firm formation in Sweden is further not markedly different from other countries such as the U.S.A., Brazil or Denmark (Andersson and Klepper, 2013). We thus see no reason why results found in this paper would not be replicated elsewhere.

\section{References}

Anderson, Patricia M., and Bruce D. Mayer (1994): "The extent and consequences of job turnover." Brookings Papers on Economic Activity: Microeconomics, 177-236.

Andersson, Martin, and Steven Klepper (2013): "Characteristics and performance of new firms and spinoffs in Sweden." Industrial and Corporate Change, 22(1): 245-80.

Arches, Joan (1991): "Social structure, burnout, and job satisfaction." Social Work, 36(3): 202-206.

Åstebro, Thomas, Jing Chen, and Peter Thompson (2011): "Stars and misfits: Self-employment and labor market frictions." Management Science, 57(11): 1999-2017.

Åstebro, Thomas, and Peter Thompson (2011): "Entrepreneurs: Jacks of all trades or hobos?" Research Policy, 40(5): 637-649.

Benz, Matthias and Bruno S. Frey (2008a): "Being independent is a great thing: Subjective evaluations of self-employment and hierarchy." Economica, 75(298):362-383.

Benz, Matthias and Bruno S. Frey (2008b): "The value of doing what you like: Evidence from the self-employed in 23 countries." Journal of Economic Behavior \& Organization, 68(3-4):445-455.

Bernard, Andrew B., J. Bradford Jensen, Stephen J. Redding, and Peter K. Schott (2007): "Firms in international trade." Journal of Economic Perspectives, 21(3):105-130.

Blanchflower, David (2000): "Self-employment in OECD countries." Labour Economics, 7(5):471-505.

${ }^{25}$ For the majority of the $20^{\text {th }}$ century, annual average wage increases were set by "collective bargaining" between the three major labor unions and the three major employers. However, between 1970 and 1990 centralized control over wages was progressively dismantled, and it was abandoned entirely in 1997. Further deregulation in the early 1990s gave rise to a dual labor market consisting of temporary and permanently-employed workers. These and other changes induced an increase in the Gini coefficient for income from 0.199 in 1981 to 0.332 in 2007 (http://www.scb.se/Pages/TableAndChart_163550.aspx). The 2007 figure places Sweden at the OECD average (The Economist, 2013). 
Blanchflower, David G., and Andrew J. Oswald (1998): “What makes an entrepreneur?" Journal of Labor Economics, 16(1):26-60.

Caliendo, Lorenzo, Ferdinando Monte, and Esteban Rossi-Hansberg (2015): "The anatomy of French production hierarchies." Journal of Political Economy, 123(4):809-85 .

Caliendo, Lorenzo, and Esteban Rossi-Hansberg (2012): "The impact of trade on organization and productivity." Quarterly Journal of Economics, 127(3):1393-1467.

Carter, Nancy M., and Thomas L. Keon (1986): "The rise and fall of the division of labour, the Past 25 Years." Organization Studies, 7(1):54-57.

Chen, Jing (2012): “The small firm effect and the quality of entrepreneurs.” Working paper, Copenhagen Business School.

Chen, Li-Wei, and Peter Thompson (2016): "Skill Balance and Entrepreneurship. Evidence from Online Career Histories." Entrepreneurship Theory and Practice, 40(2):289-305.

Dobrev, Stanislav D. and William P. Barnett (2005): "Organizational roles and transition to entrepreneurship." Academy of Management Journal, 48(3): 433-449.

Elfenbein, Daniel W., Barton H. Hamilton, and Todd R. Zenger (2010): "The small firm effect and the entrepreneurial spawning of scientists and engineers." Management Science, 56(4):659-681.

Finlay, William, Jack K. Martin, Paul M. Roman and Terry C. Blum (1995): “Organizational structure and job satisfaction: Do bureaucratic organizations produce more satisfied employees?" Administration \& Society, 27(3):427-450.

Friedrich, Benjamin (2015): “Trade shocks, firm hierarchies and wage inequality.” Manuscript, Yale University.

Fuchs-Schundeln, Nicola (2009): "On preferences for being self-employed." Journal of Economic Behavior \& Organization, 71(2):162-171.

Garicano, Luis (2000): "Hierarchies and the organization of knowledge in production." Journal of Political Economy, 108(5):874-904.

Garicano, Luis, and Esteban Rossi-Hansberg (2004): "Inequality and the organization of knowledge. "American Economic Review, 94(2):97-202.

Gompers, Paul, Josh Lerner, and David Scharfstein (2005): "Entrepreneurial spawning: Public corporations and the genesis of new ventures, 1986 to 1999." Journal of Finance, 60(2): 577-614.

Griffin, Ricky W., and Gregory Moorehead (2014): Organizational Behavior: Managing People and Organizations, Mason, $\mathrm{OH}$ : Cengage Learning.

Hackman, J. Richard, and Greg R. Oldham (1976): "Motivation through the design of work: Test of a theory." Organizational Behavior and Human Performance, 16(2):250-79.

Halaby, Charles N. (2003): "Where job values come from. Family and schooling background, cognitive ability, and gender." American Sociological Review, 68:251-278.

Haltiwanger, John, Ron S. Jarmin, and Javier Miranda (2013): "Who creates jobs? Small vs. large vs. young." Review of Economics and Statistics, 95(2):347-361.

Hamilton, Barton (2000): "Does entrepreneurship pay? An empirical analysis of the returns to self-employment." Journal of Political Economy, 108(3): 604-631.

Hausman, Jerry, and Daniel McFadden (1984): "Specification tests for the multinomial logit 
model." Econometrica, 52(5): 1219-1240.

Henrekson, Magnus and Tino Sanandaji (2014): "Billionaire entrepreneurs: A systematic analysis." PNAS, Proceedings of the National Academy of Sciences. 111(5): 1760-65.

Hummels, David, Rasmus Jørgensen, Jakob Munch, and Chong Xiang (2014): "The wage effects of offshoring: Evidence from Danish matched worker-firm data." American Economic Review, 104(6):1597-1629.

Hundley, Greg (2001): "Why and when are the self-employed more satisfied with their work?" Industrial Relations, 40(2):293-316.

Jovanovic, Boyan (1979): "Job matching and the theory of turnover." Journal of Political Economy, 87(5, Part 1): 972-990.

Kacperczyk, Aleksandra J. (2012): "Opportunity structures in established firms: Entrepreneurship versus intrapreneurship in mutual funds." Administrative Science Quarterly, 57(3):484-521.

Kawaguchi, D. (2008): "Self-employment rents: Evidence from job satisfaction scores." $\mathrm{Hi}$ totsubashi Journal of Economics, 49(1):35-45.

Lazear, Edward P. (2005):"Entrepreneurship." Journal of Labor Economics, 23(4):649-680.

Lazear, Edward P. and Paul Oyer (2004): "Internal and external labor markets: a personnel economics approach," Labour Economics, 11(5): 527-554.

Lazear, Edward P., and Kathryn L. Shaw, (2008)" "Introduction: Wage structure, raises and mobility: International comparisons of the structure of wages within and across firms." In E. Lazear and K. Shaw eds., The Structure of Wages: An International Comparison, University of Chicago Press.

Prottas, David J., and Cynthia A. Thompson (2006): "Stress, satisfaction, and the work-family interface: A comparison of self-employed business owners, independents, and organizational employees." Journal of Occupational Health Psychology, 11(4):366-378.

Rousseau, Denise M. (1977): "Technological differences in job characteristics, employee satisfaction, and motivation: A synthesis of job design research and sociotechnical systems theory." Organizational Behavior and Human Performance, 19(1):18-42.

Sørensen, Jesper (2007): "Bureaucracy and entrepreneurship: Workplace effects on entrepreneurial entry." Administrative Science Quarterly, 52:387-412.

Tåg, Joacim (2013): "Production hierarchies in Sweden." Economics Letters, 121(2):210213.

Taylor, Mark P. (1996): "Earnings, independence or unemployment: Why become self-employed?" Oxford Bulletin of Economics and Statistics, 58(2):253-266.

The Economist (2013): "The ins and the outs. Immigration and growing inequality are making the Nordics less homogeneous." The Economist, February 2nd, 2013.

Silva, Olmo (2007): "The Jack-of-all-trades entrepreneur: Innate talent or acquired skill?" Economics Letters, 97(2):118-123.

Wagner, Joachim (2003): "Testing Lazear's Jack-of-all-trades view of entrepreneurship with German micro data." Applied Economics Letters, 10(11):687-689.

Wagner, Joachim (2004): “Are young and small firms hothouses for nascent entrepreneurs?" Applied Economics Quarterly, 50:379-391. 
Wagner, Joachim (2006): "Are nascent entrepreneurs 'Jacks-of-all-trades?' A test of Lazear's theory of entrepreneurship with German data." Applied Economics, 38(20):24152419.

Walker, C.R. and R. Guest (1952): The Man on the Assembly Line. Cambridge: MA: Harvard University Press. 


\title{
Appendix to \\ Hierarchies and Entrepreneurship
}

\author{
Not intended for publication
}

Table of Contents

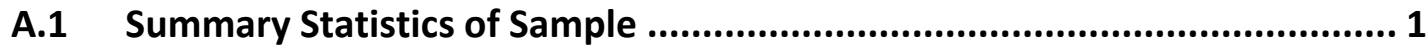

A.2 Firm-level Correlation Matrix .................................................................... 3

A.3 Worker-level Correlation Matrix ............................................................ 3

A.4 Layer-by-size Tabulation............................................................................ 3

A.5 90 \% Accurate Occupation Data for Workers ............................................ 4

A.6 95 \% Accurate Occupation Data for Workers ............................................ 5

A.7 99 \% Accurate Occupation Data for Workers ............................................6

A.8 Earnings Distributions Across Ranks for a) Narrower Classification of CEOs; and b) Total Income................................................................................. 7

A.9 Transitions to Unemployment Included in Multinomial Logit ..................... 8

A.10 Performance of Entrepreneurs Four Years after Business Creation ......... 9

A.11 Sample Weighted Regression.............................................................. 10 


\section{A.1 Summary Statistics of Sample}

Table A1

Summary Statistics on Sample

\begin{tabular}{|c|c|c|c|c|}
\hline \multicolumn{5}{|l|}{ Panel A: Firm Level Comparison } \\
\hline \multirow[b]{3}{*}{ Firm Size } & \multicolumn{2}{|c|}{ Base Sample } & \multicolumn{2}{|c|}{ Final Sample } \\
\hline & \multirow{2}{*}{$\begin{array}{l}\text { Mean } \\
23.23\end{array}$} & $\begin{array}{l}\text { Standard } \\
\text { deviation }\end{array}$ & \multirow{2}{*}{$\begin{array}{l}\text { Mean } \\
89.11\end{array}$} & \multirow{2}{*}{$\begin{array}{r}\begin{array}{r}\text { Standard } \\
\text { deviation }\end{array} \\
775.0\end{array}$} \\
\hline & & 337.0 & & \\
\hline Firm Age & 13.36 & 12.69 & 17.39 & 16.42 \\
\hline Number of Layers & - & - & 2.47 & 0.72 \\
\hline Span of Control & - & - & 6.18 & 17.46 \\
\hline \multicolumn{5}{|l|}{ Industry $(\%)$} \\
\hline Manufacturing & 12.13 & & 16.79 & \\
\hline Wholesale and Retail & 23.21 & & 23.71 & \\
\hline Real Estate/Renting/Bus.Act & 18.94 & & 17.02 & \\
\hline Education & 2.33 & & 3.81 & \\
\hline Health and Social Work & 3.45 & & 4.34 & \\
\hline Other & 39.93 & & 34.32 & \\
\hline \multicolumn{5}{|l|}{ Location (\%) } \\
\hline Stockholm & 24.46 & & 23.92 & \\
\hline Östra Mellansverige & 14.70 & & 14.66 & \\
\hline Småland med Öarna & 9.16 & & 9.70 & \\
\hline Sydsverige & 13.90 & & 14.05 & \\
\hline Västsverige & 19.97 & & 20.03 & \\
\hline Norra Mellansverige & 8.72 & & 8.72 & \\
\hline Mellersta Norrland & 4.10 & & 3.91 & \\
\hline Övre Norrland & 4.98 & & 5.01 & \\
\hline Firm-year observations & 1,36 & & 243 & 89 \\
\hline
\end{tabular}

Continued on next page 


\section{Continued from previous page}

Panel B: Individual Level Comparison

\begin{tabular}{|c|c|c|c|c|}
\hline \multirow[b]{3}{*}{ Age } & \multicolumn{2}{|c|}{ Base sample } & \multicolumn{2}{|c|}{ Final Sample } \\
\hline & Mean & $\begin{array}{l}\text { Standard } \\
\text { deviation }\end{array}$ & Mean & $\begin{array}{l}\text { Standard } \\
\text { deviation }\end{array}$ \\
\hline & 40.75 & 11.18 & 42.29 & 10.73 \\
\hline Tenure & 4.991 & 5.009 & 6.020 & 5.200 \\
\hline Female & 0.494 & 0.500 & 0.544 & 0.498 \\
\hline Education & 3.533 & 1.129 & 3.650 & 1.152 \\
\hline Wage & 260.0 & 180.7 & 272.4 & 166.0 \\
\hline Wage Growth & 0.321 & 0.720 & 0.276 & 0.628 \\
\hline \multicolumn{5}{|l|}{ Transitions } \\
\hline Stay & \multicolumn{2}{|l|}{86.33} & \multicolumn{2}{|l|}{90.26} \\
\hline Entrepreneurship & \multicolumn{2}{|l|}{0.11} & \multicolumn{2}{|l|}{0.06} \\
\hline Self-employment & \multicolumn{2}{|l|}{0.57} & \multicolumn{2}{|l|}{0.28} \\
\hline Other Incumbent & \multicolumn{2}{|l|}{12.99} & \multicolumn{2}{|l|}{9.41} \\
\hline Worker-year observations & \multicolumn{2}{|c|}{$26,399,697$} & \multicolumn{2}{|c|}{$16,485,527$} \\
\hline \multicolumn{5}{|c|}{$\begin{array}{l}\text { Notes. This table displays summary statistics on the base sample of all firms and workers in } \\
\text { firms with more than one employee and the final sample we use in the analysis. All differences } \\
\text { displayed in this table are statistically significant at the } 1 \% \text { level on account of the sample size. } \\
\text { Firms in our sample are not a representative sample of the entire population of firms. The } \\
\text { reason is that occupation data is available primarily for larger firms and has greater coverage } \\
\text { in some industries than others. Our findings should, however, be representative of the entire } \\
\text { population of larger firms. The occupation data is either collected for all firms above a size } \\
\text { cutoff or collected through random sampling of firms conditional on firm size and industry } \\
\text { affiliation. Because our regressions control for both firm size, firm age, year, and industry, we } \\
\text { should obtain good representation of the population of larger firms. }\end{array}$} \\
\hline
\end{tabular}




\section{A.2 Firm-level Correlation Matrix}

Table A2

Firm-level Correlation Matrix.

\begin{tabular}{lcccc}
\hline \hline & Layers & Span & Size & Age \\
Layers & 1 & & & \\
Span & 0.0393 & 1 & 1 & \\
Size & 0.1959 & 0.1092 & 0.0795 & 1 \\
Age & 0.2710 & 0.0512 & & \\
\hline \hline
\end{tabular}

Notes. $\mathrm{N}=243,689$.

\section{A.3 Worker-level Correlation Matrix}

Table A3

Worker-level correlation matrix

\begin{tabular}{lcccccc}
\hline \hline & Age & Tenure & Female & Education & Wage & Wage Gr. \\
Age & 1 & & & & & \\
Tenure & 0.4409 & 1 & & & & \\
Female & 0.4409 & 0.0705 & 1 & & & \\
Education & -0.0623 & -0.0515 & 0.1084 & 1 & & \\
Wage & 0.1659 & 0.0528 & -0.2904 & 0.2123 & 1 & 1 \\
Wage Gr. & -0.3373 & -0.3208 & 0.0047 & 0.0533 & 0.0050 & 1 \\
\hline \hline
\end{tabular}

Notes. $\mathrm{N}=16,485,527$.

\section{A.4 Layer-by-size Tabulation}

Table A4

Number of Firm-year Observations

\begin{tabular}{lrrrrrr}
\hline \hline & \multicolumn{5}{c}{ Size Categories } \\
& \multicolumn{1}{c}{50} & $50-100$ & $100-500$ & $500-1500$ & $>1500$ & \multicolumn{1}{l}{ Total } \\
2 Layers & 157,403 & 3,345 & 104 & 55 & 18 & 161.861 \\
3 Layers & 38,126 & 5,855 & 4,312 & 581 & 169 & 49.043 \\
4 Layers & 12,736 & 6,463 & 8,219 & 3,096 & 2,271 & 32.785 \\
Total & 208,265 & 15,663 & 13,571 & 3,732 & 2,458 & 243.689 \\
\hline \hline
\end{tabular}

Notes. This table reports the number of firm-year observations within each layer and size bin. 


\section{A.5 $90 \%$ Accurate Occupation Data for Workers}

Table A5

Worker Transitions. Multinomial Logit Estimation

\begin{tabular}{lccc}
\hline \hline & $\begin{array}{c}\text { Entrepreneurship } \\
(1)\end{array}$ & $\begin{array}{c}\text { Self-employment } \\
(2)\end{array}$ & $\begin{array}{c}\text { Other firm } \\
(3)\end{array}$ \\
\hline Firm layers: 3 & $-0.920^{* * *}$ & $-0.730^{* * *}$ & $-0.295^{* * *}$ \\
& $(0.0636)$ & $(0.0399)$ & $(0.0696)$ \\
Firm layers: 4 & $-1.268^{* * *}$ & $-0.936^{* * *}$ & $-0.369^{* * *}$ \\
& $(0.0639)$ & $(0.0448)$ & $(0.0767)$ \\
Span of control & $1.32 \mathrm{e}-05$ & -0.000577 & $0.00185^{* * *}$ \\
& $(0.000435)$ & $(0.000353)$ & $(0.000662)$ \\
\hline CE0s and Directors & $1.324^{* * *}$ & $0.206^{* * *}$ & 0.0469 \\
& $(0.0855)$ & $(0.0598)$ & $(0.0798)$ \\
Senior staff & $0.981^{* * *}$ & $0.223^{* * *}$ & $0.198^{* * *}$ \\
& $(0.0737)$ & $(0.0450)$ & $(0.0633)$ \\
Supervisors & $0.561^{* * *}$ & $0.189^{* * *}$ & -0.0449 \\
& $(0.0501)$ & $(0.0283)$ & $(0.0927)$ \\
\hline \hline
\end{tabular}

Notes. This table reports regressions that restrict attention to firms with $90 \%$ accurate occupation data. $N=11,482,968$. Standard errors in parentheses. ${ }^{* * *} \mathrm{p}<0.01,{ }^{* *} \mathrm{p}<0.05$, * $\mathrm{p}<0.1$. Regressions include industry, region, and year fixed effects; and dummies indicating whether data on firm age and employee tenure are truncated. The standard errors are clustered at the firm level. Additional regressors, not reported, are the same as in Table 6. The standard errors are clustered at the firm level. 


\section{A.6 $95 \%$ Accurate Occupation Data for Workers}

Table A6

Worker Transitions. Multinomial Logit Estimation

\begin{tabular}{lccc}
\hline \hline & $\begin{array}{c}\text { Entrepreneurship } \\
(1)\end{array}$ & $\begin{array}{c}\text { Self-employment } \\
(2)\end{array}$ & $\begin{array}{c}\text { Other firm } \\
(3)\end{array}$ \\
\hline Firm layers: 2 & $-1.025^{* * *}$ & $-0.768^{* * *}$ & $-0.247^{* * *}$ \\
& $(0.0827)$ & $(0.0556)$ & $(0.0869)$ \\
Firm layers: 3 & $-1.383^{* * *}$ & $-1.035^{* * *}$ & $-0.378^{* * *}$ \\
& $(0.0778)$ & $(0.0618)$ & $(0.0763)$ \\
Span of control & $-5.67 \mathrm{e}-05$ & $-0.00120^{*}$ & $0.00246^{* *}$ \\
& $(0.000686)$ & $(0.000619)$ & $(0.00103)$ \\
\hline CEOs and Directors & $1.174^{* * *}$ & $0.200^{* * *}$ & -0.0246 \\
& $(0.102)$ & $(0.0718)$ & $(0.0500)$ \\
Senior staff & $0.823^{* * *}$ & $0.216^{* * *}$ & $0.319^{* * *}$ \\
& $(0.105)$ & $(0.0700)$ & $(0.0866)$ \\
Supervisors & $0.463^{* * *}$ & $0.185^{* * *}$ & $0.200^{* * *}$ \\
& $(0.0701)$ & $(0.0362)$ & $(0.0624)$ \\
\hline \hline
\end{tabular}

Notes. This table reports regressions that restrict attention to firms with $95 \%$ accurate occupation data. $N=4,324,587$. Standard errors in parentheses. ${ }^{* * *} \mathrm{p}<0.01,{ }^{* *} \mathrm{p}<0.05$, ${ }^{*}$ $\mathrm{p}<0.1$. Regressions include industry, region, and year fixed effects; and dummies indicating whether data on firm age and employee tenure are truncated. The standard errors are clustered at the firm level. Additional regressors, not reported, are the same as in Table 6. The standard errors are clustered at the firm level. 


\section{A.7 $99 \%$ Accurate Occupation Data for Workers}

Table A7

Worker Transitions. Multinomial Logit Estimation

\begin{tabular}{lccc}
\hline \hline & $\begin{array}{c}\text { Entrepreneurship } \\
(1)\end{array}$ & $\begin{array}{c}\text { Self-employment } \\
(2)\end{array}$ & $\begin{array}{c}\text { Other firm } \\
(3)\end{array}$ \\
\hline Firm layers: 2 & $-0.546^{* * *}$ & $-0.393^{* * *}$ & 0.0509 \\
& $(0.0909)$ & $(0.0576)$ & $(0.0683)$ \\
Firm layers: 3 & $-1.128^{* * *}$ & $-0.541^{* * *}$ & -0.190 \\
& $(0.137)$ & $(0.0869)$ & $(0.136)$ \\
Span of control & $-0.0404^{* * *}$ & $-0.00959^{* *}$ & $0.00618^{* * *}$ \\
& $(0.00715)$ & $(0.00417)$ & $(0.000916)$ \\
\hline CE0s and Directors & $0.980^{* * *}$ & $0.218^{* * *}$ & $-0.229^{* * *}$ \\
& $(0.115)$ & $(0.0800)$ & $(0.0391)$ \\
Senior staff & $0.872^{* * *}$ & $0.416^{* * *}$ & $0.207^{* * *}$ \\
& $(0.166)$ & $(0.121)$ & $(0.0566)$ \\
Supervisors & $0.395^{* * *}$ & $0.192^{* * *}$ & $0.0631^{*}$ \\
& $(0.0842)$ & $(0.0461)$ & $(0.0356)$ \\
\hline \hline
\end{tabular}

Notes. This table reports regressions that restrict attention to firms with $99 \%$ accurate occupation data. $N=640,627$. Standard errors in parentheses. ${ }^{* * *} \mathrm{p}<0.01,{ }^{* *} \mathrm{p}<0.05,{ }^{*}$ $\mathrm{p}<0.1$. Regressions include industry, region, and year fixed effects; and dummies indicating whether data on firm age and employee tenure are truncated. The standard errors are clustered at the firm level. Additional regressors, not reported, are the same as in Table 6. The standard errors are clustered at the firm level. 


\section{A.8 Earnings Distributions Across Ranks for a) Narrower Classification of CEOs; and b) Total Income}

Table A8a

Wage distribution for Narrower Classification of CEOs and Directors

\begin{tabular}{lccccccc}
\hline \hline \multirow{2}{*}{ Rank } & Mean & \multicolumn{5}{c}{ Percentiles } & \multirow{2}{*}{ Wage } \\
\cline { 3 - 7 } & & $10^{\text {th }}$ & $25^{\text {th }}$ & $50^{\text {th }}$ & $75^{\text {th }}$ & $90^{\text {th }}$ & Dispersion \\
\hline 4. CEOs and directors & 1,011 & 322 & 390 & 536 & 763 & 1,132 & 1,755 \\
3. Senior staff & 505 & 293 & 359 & 444 & 575 & 761 & 678 \\
4. Supervisors & 308 & 159 & 228 & 285 & 359 & 469 & 453 \\
1. Production workers & 219 & 112 & 172 & 222 & 266 & 313 & 264 \\
\hline Mean & 272 & 131 & 195 & 251 & 317 & 415 & 373 \\
\hline \hline
\end{tabular}

Notes. This table displays the wage distribution across occupation classes based on SSYK but with "Rank 3. CEOs and directors" corresponding only to workers with SSYK code 121 (Directors and chief executives). Data are in units of 1,000 SEK in 2005 prices. Sample sizes are as follows. Rank 4: 45,868. Rank 3: 607,753. Rank 2: 7,302,636. Rank 1: 8,376,591.

Table A8b

Total income (wage + capital income) distribution

\begin{tabular}{lccccccc}
\hline \multirow{2}{*}{ Rank } & Mean & \multicolumn{5}{c}{ Percentiles } & Wage \\
\cline { 3 - 7 } & & $10^{\text {th }}$ & $25^{\text {th }}$ & $50^{\text {th }}$ & $75^{\text {th }}$ & $90^{\text {th }}$ & Dispersion \\
\hline 4. CEOs and directors & 585 & 204 & 271 & 357 & 572 & 985 & 1,265 \\
3. Senior staff & 509 & 276 & 342 & 430 & 568 & 774 & 737 \\
2. Supervisors & 304 & 148 & 217 & 276 & 352 & 469 & 467 \\
1. Production workers & 213 & 106 & 165 & 214 & 258 & 307 & 267 \\
\hline Mean & 269 & 123 & 186 & 242 & 309 & 412 & 389 \\
\hline \hline
\end{tabular}

Notes. This table displays the distribution of total earnings across broad occupation classes based on SSYK. 


\section{A.9 Transitions to Unemployment Included in Multinomial Logit}

Table A9

Worker Transitions. Multinomial Logit Estimation

\begin{tabular}{lcccc}
\hline \hline & $\begin{array}{c}\text { Entrepreneur- } \\
\text { ship }\end{array}$ & $\begin{array}{c}\text { Self-employ- } \\
\text { ment }\end{array}$ & Other firm & Unemployment \\
& $(1)$ & $(2)$ & $(3)$ & $(4)$ \\
\hline Firm layers: 2 & $-0.725^{* * *}$ & $-0.535^{* * *}$ & $-0.134^{* * *}$ & $-0.0689^{* * *}$ \\
& $(0.0455)$ & $(0.0272)$ & $(0.0450)$ & $(0.0248)$ \\
Firm layers: 3 & $-1.073^{* * *}$ & $-0.718^{* * *}$ & $-0.244^{* * *}$ & $-0.127 * * *$ \\
& $(0.0494)$ & $(0.0337)$ & $(0.0478)$ & $(0.0310)$ \\
Span of control & -0.000358 & $-0.000951^{* * *}$ & $0.00112^{* * *}$ & $-8.49 \mathrm{e}-05$ \\
& $(0.000412)$ & $(0.000288)$ & $(0.000415)$ & $(0.000318)$ \\
\hline CEOs and Directors & $1.410^{* * *}$ & $0.368^{* * *}$ & 0.0356 & $-0.478^{* * *}$ \\
& $(0.0726)$ & $(0.0486)$ & $(0.0491)$ & $(0.0454)$ \\
Senior staff & $0.978^{* * *}$ & $0.366^{* * *}$ & $0.177^{* * *}$ & $-0.759 * * *$ \\
& $(0.0550)$ & $(0.0348)$ & $(0.0353)$ & $(0.0406)$ \\
Supervisors & $0.605^{* * *}$ & $0.249 * * *$ & -0.0179 & $-0.399 * * *$ \\
& $(0.0387)$ & $(0.0238)$ & $(0.0527)$ & $(0.0280)$ \\
\hline \hline
\end{tabular}

Notes. This table included moves to unemployment as an outcome. There are 202,136 workers than transition to unemployment, so sample size increases to $N=16,687,663$. Standard errors in parentheses. ${ }^{* * *} \mathrm{p}<0.01,{ }^{* *} \mathrm{p}<0.05,{ }^{*} \mathrm{p}<0.1$. Regressions include industry, region, and year fixed effects; and dummies indicating whether data on firm age and employee tenure are truncated. The standard errors are clustered at the firm level. Additional regressors, not reported, are the same as in Table 6. The standard errors are clustered at the firm level. 


\section{A.10 Performance of Entrepreneurs Four Years after Business Creation}

Table A10

Performance of entrepreneurs, four years after business creation

\begin{tabular}{|c|c|c|c|c|}
\hline & \multicolumn{4}{|c|}{ OLS Regressions } \\
\hline & \multicolumn{2}{|c|}{ Log(Total income) } & \multicolumn{2}{|c|}{ Survival } \\
\hline & $\begin{array}{c}\text { Entrepreneurs } \\
\text { (1) }\end{array}$ & $\begin{array}{c}\text { Self-employed } \\
\text { (2) }\end{array}$ & $\begin{array}{c}\text { Entrepreneurs } \\
\text { (3) }\end{array}$ & $\begin{array}{c}\text { Self-employed } \\
\text { (4) }\end{array}$ \\
\hline \multirow[t]{2}{*}{ Firm layers: 2} & -0.00835 & 0.0945 & -0.0201 & $-0.0269^{* * *}$ \\
\hline & $(0.0299)$ & $(0.0778)$ & $(0.0203)$ & (0.00973) \\
\hline \multirow[t]{2}{*}{ Firm layers: 3} & 0.0116 & 0.0733 & -0.0228 & $-0.0502^{* * *}$ \\
\hline & $(0.0285)$ & $(0.0722)$ & $(0.0194)$ & $(0.00908)$ \\
\hline \multirow[t]{2}{*}{ CEOs and Directors } & $0.121^{* *}$ & $0.718^{* * *}$ & $-0.0936^{* * *}$ & $-0.154^{* * *}$ \\
\hline & $(0.0528)$ & $(0.219)$ & $(0.0287)$ & $(0.0210)$ \\
\hline \multirow[t]{2}{*}{ Managers } & $0.165^{* * *}$ & 0.197 & $-0.0544^{* *}$ & $-0.0972^{* * *}$ \\
\hline & $(0.0385)$ & $(0.139)$ & $(0.0263)$ & $(0.0159)$ \\
\hline \multirow[t]{2}{*}{ Supervisors } & $0.118^{* * *}$ & $0.156^{* * *}$ & -0.0291 & $-0.0290^{* * *}$ \\
\hline & $(0.0274)$ & $(0.0592)$ & $(0.0178)$ & $(0.00713)$ \\
\hline \multirow[t]{2}{*}{ Firm Size } & $-4.31 e-06$ & $7.60 \mathrm{e}-06$ & $-6.08 \mathrm{e}-06^{* *}$ & $-3.26 \mathrm{e}-06^{* * *}$ \\
\hline & $(4.91 \mathrm{e}-06)$ & (8.31e-06) & $(2.82 \mathrm{e}-06)$ & $(1.10 \mathrm{e}-06)$ \\
\hline \multirow[t]{2}{*}{ Firm Size ${ }^{\wedge} 2$} & $2.05 \mathrm{e}-10^{*}$ & $-2.15 e-10$ & $1.18 \mathrm{e}-10^{* *}$ & $5.97 \mathrm{e}-11^{* * *}$ \\
\hline & $(1.15 \mathrm{e}-10)$ & $(1.94 \mathrm{e}-10)$ & $(5.70 \mathrm{e}-11)$ & $(0)$ \\
\hline \multirow[t]{2}{*}{ Firm Age } & 0.000182 & 0.00243 & 0.00143 & -0.000282 \\
\hline & $(0.00142)$ & $(0.00302)$ & $(0.000988)$ & (0.000391) \\
\hline \multirow[t]{2}{*}{ Firm Age $^{\wedge} 2$} & $4.83 e-06$ & $-1.82 \mathrm{e}-05$ & $-1.15 e-05$ & $5.74 \mathrm{e}-06$ \\
\hline & $(1.47 e-05)$ & $(2.94 \mathrm{e}-05)$ & $(1.01 \mathrm{e}-05)$ & $(3.96 \mathrm{e}-06)$ \\
\hline \multirow[t]{2}{*}{ Log(wage) } & $0.290^{* * *}$ & $0.370^{* * *}$ & $0.0405^{* * *}$ & $-0.0138^{* * *}$ \\
\hline & $(0.0293)$ & $(0.0329)$ & $(0.0132)$ & $(0.00377)$ \\
\hline \multirow[t]{2}{*}{ 3yr wage growth } & $-0.0752^{* * *}$ & $-0.114^{* * *}$ & -0.0173 & -0.00168 \\
\hline & $(0.0213)$ & $(0.0313)$ & $(0.0113)$ & $(0.00346)$ \\
\hline Observations & 4,057 & 7,204 & 6,546 & 34,465 \\
\hline$R$ squared & 0.174 & 0.062 & 0.040 & 0.017 \\
\hline
\end{tabular}

Notes. This table presents results of regressions explaining the performance of entrepreneurs for four years after business creation. Standard errors in parentheses. ${ }^{* * *} \mathrm{p}<0.01,{ }^{* *} \mathrm{p}<0.05,{ }^{*}$ $\mathrm{p}<0.1$. Regressions include a constant term, and controls for age, age squared, gender, education, tenure, tenure squared, industry, region, and year. Total income is the sum of capital and labor income accruing to the individual four years after business creation. Success is equal to one if a business created is active, in the sense that it has more than one employee (including the founder), four years after business creation. The standard errors are clustered at the firm level. 


\section{A.11 Sample Weighted Regression}

Table A11

Worker Transitions. Multinomial Logit Estimation

\begin{tabular}{|c|c|c|c|}
\hline & $\begin{array}{c}\text { Entrepreneurship } \\
(1)\end{array}$ & $\begin{array}{c}\text { Self-employment } \\
(2)\end{array}$ & $\begin{array}{l}\text { Other firm } \\
\text { (3) }\end{array}$ \\
\hline Firm layers: 2 & $\begin{array}{l}-0.677^{* * *} \\
(0.0489)\end{array}$ & $\begin{array}{l}-0.553^{* * *} \\
(0.0284)\end{array}$ & $\begin{array}{l}-0.129^{* * *} \\
(0.0325)\end{array}$ \\
\hline Firm layers: 3 & $\begin{array}{l}-1.027^{* * *} \\
(0.0502)\end{array}$ & $\begin{array}{l}-0.721^{* * *} \\
(0.0311)\end{array}$ & $\begin{array}{l}-0.263^{* * *} \\
(0.0357)\end{array}$ \\
\hline CEOs and Directors & $\begin{array}{l}1.645^{* * *} \\
(0.0772)\end{array}$ & $\begin{array}{l}0.350 * * * \\
(0.0577)\end{array}$ & $\begin{array}{l}-0.0728^{* *} \\
(0.0350)\end{array}$ \\
\hline Senior staff & $\begin{array}{l}1.157^{* * *} \\
(0.0713)\end{array}$ & $\begin{array}{l}0.251^{* * *} \\
(0.0377)\end{array}$ & $\begin{array}{l}0.118^{* * *} \\
(0.0253)\end{array}$ \\
\hline Supervisors & $\begin{array}{l}0.670^{* * *} \\
(0.0492) \\
\end{array}$ & $\begin{array}{l}0.198 * * * \\
(0.0274)\end{array}$ & $\begin{array}{l}-0.0289 \\
(0.0368) \\
\end{array}$ \\
\hline Firm size & $\begin{array}{c}-0.000107^{* * *} \\
(1.25 \mathrm{e}-05)\end{array}$ & $\begin{array}{c}-8.35 \mathrm{e}-05^{* * *} \\
(8.85 \mathrm{e}-06)\end{array}$ & $\begin{array}{c}-2.77 e-05 \\
(1.83 e-05)\end{array}$ \\
\hline Firm size squared & $\begin{array}{c}2.05 \mathrm{e}-09 * * * \\
(2.47 \mathrm{e}-10)\end{array}$ & $\begin{array}{c}1.55 \mathrm{e}-09 * * * \\
(1.77 \mathrm{e}-10)\end{array}$ & $\begin{array}{c}5.00 \mathrm{e}-10 \\
(3.36 \mathrm{e}-10)\end{array}$ \\
\hline Firm age & $\begin{array}{l}-0.00303 \\
(0.00239)\end{array}$ & $\begin{array}{c}-0.00449 * * * \\
(0.00153)\end{array}$ & $\begin{array}{l}-0.00247 \\
(0.00240)\end{array}$ \\
\hline Firm age squared & $\begin{array}{c}2.54 \mathrm{e}-07 \\
(2.21 \mathrm{e}-05)\end{array}$ & $\begin{array}{c}1.03 \mathrm{e}-05 \\
(1.41 \mathrm{e}-05)\end{array}$ & $\begin{array}{c}1.11 \mathrm{e}-06 \\
(2.17 \mathrm{e}-05)\end{array}$ \\
\hline Age (years) & $\begin{array}{l}0.136^{* * *} \\
(0.0127)\end{array}$ & $\begin{array}{c}0.125^{* * *} \\
(0.00550)\end{array}$ & $\begin{array}{c}-0.0497^{* * *} \\
(0.00272)\end{array}$ \\
\hline Age squared & $\begin{array}{l}-0.00175^{* * *} \\
(0.000147)\end{array}$ & $\begin{array}{l}-0.00132^{* * *} \\
(6.70 \mathrm{e}-05)\end{array}$ & $\begin{array}{c}0.000365^{* * *} \\
(3.37 \mathrm{e}-05)\end{array}$ \\
\hline Female & $\begin{array}{l}-0.961^{* * *} \\
(0.0463)\end{array}$ & $\begin{array}{l}-0.741^{* * *} \\
(0.0193)\end{array}$ & $\begin{array}{c}-0.0927^{* * *} \\
(0.0135)\end{array}$ \\
\hline Education & $\begin{array}{l}0.0503^{* * *} \\
(0.0167)\end{array}$ & $\begin{array}{l}0.0655^{* * *} \\
(0.00949)\end{array}$ & $\begin{array}{l}0.0803^{* * *} \\
(0.00720)\end{array}$ \\
\hline Log(labor income) & $\begin{array}{c}0.204^{* *} \\
(0.0849)\end{array}$ & $\begin{array}{c}-0.623^{* * *} \\
(0.0122)\end{array}$ & $\begin{array}{l}-0.127^{* * *} \\
(0.0100)\end{array}$ \\
\hline Tenure (years) & $\begin{array}{l}-0.122^{* * *} \\
(0.00963)\end{array}$ & $\begin{array}{l}-0.206^{* * *} \\
(0.00593)\end{array}$ & $\begin{array}{c}-0.187^{* * *} \\
(0.0112)\end{array}$ \\
\hline Tenure squared & $\begin{array}{l}0.00289 * * * \\
(0.000667)\end{array}$ & $\begin{array}{l}0.00755^{* * *} \\
(0.000385)\end{array}$ & $\begin{array}{l}0.00764^{* * *} \\
(0.000548)\end{array}$ \\
\hline 3yr wage growth & $\begin{array}{l}-0.0498 \\
(0.0620)\end{array}$ & $\begin{array}{c}-0.0484 \\
(0.0354)\end{array}$ & $\begin{array}{l}-0.382^{* * *} \\
(0.0743)\end{array}$ \\
\hline
\end{tabular}

Notes. This table replicates Table 7 but uses sample weights to account for the differences between the final sample and the base sample displayed in Table A1. The sample weights are based on a logistic regression explaining being in the final sample with all the variables displayed in Table A1. $N=16,485,527$. Standard errors in parentheses.

${ }^{* * *} \mathrm{p}<0.01,{ }^{* *} \mathrm{p}<0.05,{ }^{*} \mathrm{p}<0.1$. Regressions include industry, region, and year fixed effects, and dummies indicating whether firm age and employee tenure are truncated. 